\title{
An analysis of the development of
} cauliflower seed as a model to improve the molecular mechanism of abiotic stress tolerance in cauliflower artificial seeds

Rihan, Hail

http://hdl.handle.net/10026.1/9656

10.1016/j.plaphy.2017.05.011

Plant Physiology and Biochemistry

Elsevier BV

All content in PEARL is protected by copyright law. Author manuscripts are made available in accordance with publisher policies. Please cite only the published version using the details provided on the item record or document. In the absence of an open licence (e.g. Creative Commons), permissions for further reuse of content should be sought from the publisher or author. 
Research article

\title{
An analysis of the development of cauliflower seed as a model to improve the molecular mechanism of abiotic stress tolerance in cauliflower artificial seeds
}

\author{
Hail Z. Rihan ${ }^{\mathrm{a}, *}$, Mohammed Al-Issawi ${ }^{\mathrm{b}}$, Michael P. Fuller ${ }^{\mathrm{a}}$ \\ a School of Biological and Marine Sciences, Faculty of Science and Engineering, Plymouth University, Plymouth, Devon PL4 8AA, UK \\ b Agriculture College, Al-Anbar University, Anbar, Iraq
}

\section{A R T I C L E I N F O}

\section{Article history:}

Received 6 April 2017

Received in revised form 17 May 2017

Accepted 19 May 2017

Available online $\mathrm{xxx}$

\section{Keywords:}

Dehydrin

Cauliflower

K-segment

Seed

Abiotic stress

Cold acclimation

\begin{abstract}
A B S T R A C T
The development stages of conventional cauliflower seeds were studied and the accumulation of dehydrin proteins through the maturation stages was investigated with the aim of identifying methods to improve the viability of artificial seeds of cauliflower. While carbohydrate, ash and lipids increased throughout the development of cauliflower traditional seeds, proteins increased with the development of seed and reached the maximum level after 75 days of pollination, however, the level of protein started to decrease after that. A significant increase in the accumulation of small size dehydrin proteins $(12,17,26 \mathrm{KDa})$ was observed during the development of cauliflower seeds. Several experiments were conducted in order to increase the accumulation of important dehydrin proteins in cauliflower microshoots (artificial seeds). Mannitol and ABA (Absisic acid) increased the accumulation of dehydrins in cauliflower microshoots while cold acclimation did not have a significant impact on the accumulation of these proteins. Molybdenum treatments had a negative impact on dehydrin accumulation. Dehydrins have an important role in the drought tolerance of seeds and, therefore, the current research helps to improve the accumulation of these proteins in cauliflower artificial seeds. This in turns improves the quality of these artificial seeds. The current results suggest that dehydrins do not play an important role in cold tolerance of cauliflower artificial seeds. This study could have an important role in improving the understanding of the molecular mechanism of abiotic stress tolerance in plants.
\end{abstract}

C 2017 Published by Elsevier Ltd.

\section{Introduction}

An effective protocol for cauliflower micropropagation was designed by Kieffer et al. (2001) and optimized by Rihan et al. (2011b), (2012)and enables the production of thousands of microshoots per cauliflower curd and provides an optimal system for the analysis of the physiological and molecular responses of cauliflower to various types of abiotic stresses. Moreover, these microshoots can be used for artificial seed production, which are required to show a high level of abiotic stress tolerance in order to be a cost effective method for cauliflower propagation. Insights into how to make artificial seeds more successful can come from studies of natural seed development.

Natural seed development involves a series of changes from ovule fertilization to seed maturation that is genetically controlled. This development comprises a series of morphological, physiological and biochemical changes occurring from ovule fertilization to the time when seeds become physiologically independent of the parent plant (Delouche, 1971). Fellows et al. (1979) found that the physiological maturity of orthodox-seeds generally occurs when the moisture con-

* Corresponding author.
Email addresses: hail.rihan@plymouth.ac.uk (H.Z. Rihan);
mohammedhamdan1177@yahoo.com (M. Al-Issawi); mfuller@plymouth.ac.uk (M.P. Fuller) tent declines to about $50-60 \%$ and that at this stage, the seeds exhibit the highest level of viability, vigour and dry weight. Seed maturity is normally accompanied by noticeable changes in seed and fruit colouration (Nkang, 2002). Seed development can be divided into four different stages: embryo patterning, embryo growth, seed filling and seed desiccation (Fei et al., 2007). After the completion of embryo growth, major increases include accumulation of seed storage products such as protein, oil and carbohydrate. The seed filling stage is followed by the desiccation stage during which seeds acquire drought tolerance (Bewley and Black, 1994). Coelho and Benedito (2008) divided the development of seeds into three main stages according to the dry components accumulation: the first stage is characterised by a relatively slow mass accumulation during embryogenesis. The second stage is the maturation stage, characterised by a continuous and high increase in dry matter. This stage ends by reaching the maximum dry matter content at physiological maturity. Seed dehydration is the third phase of the seed development. This stage is characterised by biological mechanisms leading to embryo desiccation resistance.

Late Embryogenesis Abundant (LEA) proteins were first described in wheat and cotton (Goyal et al., 2005) and are synthesised in abundance during seed development and can comprise up to $4 \%$ of cellular proteins (Roberts et al., 1993). LEA proteins have been linked to the embryo capability for withstanding dehydration al- 
though the mechanism of action is still not clear (Coelho and Benedito, 2008). One of the mechanisms proposed with regards to LEA functions was that these proteins might act as protectors of macro-molecular and/or cellular structures during water deficit since they preferentially network with the available water molecules and deliver a hydration shell to protect the "integrity" and function of these macro-molecules (Hoekstra et al., 2001; Garay-Arroyo et al., 2000). LEA proteins also, together with oligosaccharides and perhaps small heat shock proteins, (sHSPs), participate in the formation of the "glassy state" of the seed and its stabilization in the dehydrated state (Kalemba and Pukacka, 2008). LEA proteins increase hydrogen bonding and, thereby, the average strength of the amorphous matrix and the glass transition temperature (Wolkers et al., 2001).

LEA protein genes have been described in different plant species and six different groups of these proteins have been characterised according to their expression patterns and gene sequence. The main classes are group 1, 2 and 3 (Wise, 2003; Bray, 1993). Group 1 consists of LEA proteinsthat are found only in plants and are unstructured proteins in solution. This group of proteins has a preserved 20-residue amino acid motif, most often in one copy (Goyal et al., 2005). Group 2 LEA proteins, which are known as dehydrins, are mainly found in plants (Close et al., 1989). This group of proteins is classified in three sequence motifs described as the K-domain (lysine-rich), the Y-domain (DEYGNP) and the S-segment (poly-serine stutter) (Kalemba and Pukacka, 2008). However, the K-domain, which contains the consensus amino acid sequence EKKGIMDKIKELPG, is the only segment present in all types of dehydrins (Close, 1997). Based on the existence and combinations of segments, dehydrins are categorized into the classes $\mathrm{Y}_{\mathrm{n}} \mathrm{SK}_{2}, \mathrm{~K}_{\mathrm{n}}, \mathrm{K}_{\mathrm{n}} \mathrm{S}, \mathrm{SK}_{\mathrm{n}}$ and $\mathrm{Y}_{2} \mathrm{~K}_{\mathrm{n}}$ (Kalemba and Pukacka, 2008). Although dehydrins show some $\alpha$-helical content, they are considered to be unstructured proteins (Lisse et al., 1996; Ceccardi et al., 1994). Group 3 LEA proteins are defined by a repeated 11-mer amino acid motif. The consensus sequence of this motif has been widely described as $\Phi \Phi \mathrm{E} / \mathrm{QX} \Phi \mathrm{KE} / \mathrm{QK} \Phi \mathrm{XE} / \mathrm{D} / \mathrm{Q}$ (where $\Phi$ characterizes a hydrophobic residue). This group of proteins has been identified in the homologues of organisms other than plants (Dure, 2001).

It is widely accepted that both freezing stress and drought cause desiccation of the plant cell protoplasm (Steponkus et al., 1980). Freezing stress causes ice formation in the intercellular spaces and, since ice has a lower osmotic potential than water, water moves from inside the cells to the ice in the intercellular space resulting in desiccation of the cytosol (Thomashow, 1999). Several studies suggest that plants have similar approaches to desiccation resistance regardless of whether the desiccation is caused by drought or freezing stress and several genes have been found to respond to both drought and freezing stresses (Shinozaki and Yamaguchi-Shinozaki, 2000). It also seems that there is a physiological cross adaptation where the exposure to one stress can improve the tolerance to other stresses (Parmentier-Line et al., 2002) where drought can predispose plants to cold tolerance (Anisko and Lindstrom, 1996) and vice-versa (Levitt, 1960). It has been demonstrated that groups of dehydrin proteins are produced by conditions which have a dehydrative constituent such as drought, salinity, cold and ABA (Close, 1997). The current study aimed to investigate the developmental stages of cauliflower seeds in terms of the accumulation of seed reserve compounds (lipids, carbohydrates, minerals and proteins) and in terms of the changes in the amount of dehydrin protein which occurs. It was an aim to try to improve artificial seeds by mimicking processes occurring in conventional cauliflower seeds. Moreover, it aimed to investigate the effect of certain treatments such as Mannitol, and Molybdenum (MO) treatments which were reported to have a positive effect on cauliflower artificial seed cold tolerance (Rihan et al., 2014; Rihan, 2014), on the accumulation of dehydrin proteins in cauliflower microshoots and, therefore, to find out whether dehydrin proteins play any part in the cold tolerance of cauliflower artificial seeds (microshoots).

\section{Material and methods}

\subsection{Plant materials}

Twenty young cauliflower plants (cv Medallion, Bred by Bejo (Holland). Sold in the UK by Elsoms seeds) were obtained from a field in Cornwall, courtesy of Simmonds \& Sons Ltd, and replanted in large pots in the Skarden Garden greenhouse at the University of Plymouth. The plants were grown according to good commercial practice and fertilized appropriately and given crop protection against aphid and leaf disease as necessary. Five plants of the cultivar Fleet were cultured between the Medallion plants to facillitate sufficient open pollination between the two varieties in view of the self-incompatibility nature of cauliflower and the necessity for external pollinators. When the plants started flowering, they were covered with fleece bags for 8 days to ensure that there was a significant amount of flowers available for fertilization. The bags were then removed for a week to allow open pollination between cauliflower plants. The plants were then re-covered to stop further pollination (Fig. 1). Giving a limited period for open pollination helped to increase the level of synchronization in cauliflower seed maturation. A month later, the first sample of cauliflower seeds was collected. Subsequently, seed samples were collected five times at 15 day intervals (Fig. 2) (It was difficult to collect any more seeds after that since they had become very dry and the seeds started falling from the plants). Samples were placed in nylon bags and transferred quickly to a fridge at $4{ }^{\circ} \mathrm{C}$ and the subsequent analyses were done on the day of the sample collection or on the following day. Determination of moisture content.

Three replicates, each consisting of $5 \mathrm{~g}$ seeds, were used from each seed sample. Seeds were dried to a constant weight in an oven at $130{ }^{\circ} \mathrm{C}$. The moisture level was calculated as:

$$
\% \text { Moisture }=\frac{\mathrm{W} 1-\mathrm{W} 2}{\mathrm{~W} 1} * 100
$$

$\mathrm{W}_{1}$ : Seed fresh weight.

$\mathrm{W}_{2}$ : Seed dry weight.

\subsection{Determination of lipid content (Rapid Soxhlet Extraction)}

Rapid Soxhlet Extraction methods were used to determine the lipid content of cauliflower seeds following the procedures described by Rihan (2014). Well ground cauliflower seeds were weighed into cellulose thimbles and solvent was added. The solvent was heated to boiling point. The vapours were condensed and hot liquid solvent washed through the sample in the thimble in a continuous process. The non-volatile solutes were extracted into the solvent. After a period of time, the solvent was recovered and the extracted lipids were quantified by weighing using the following equation:

$$
\begin{aligned}
& \text { \%FAT } \\
& =\frac{\text { final weight of beaker }- \text { initial weight of beaker }}{\text { initial weight of sample }}
\end{aligned}
$$$$
* 100
$$ 


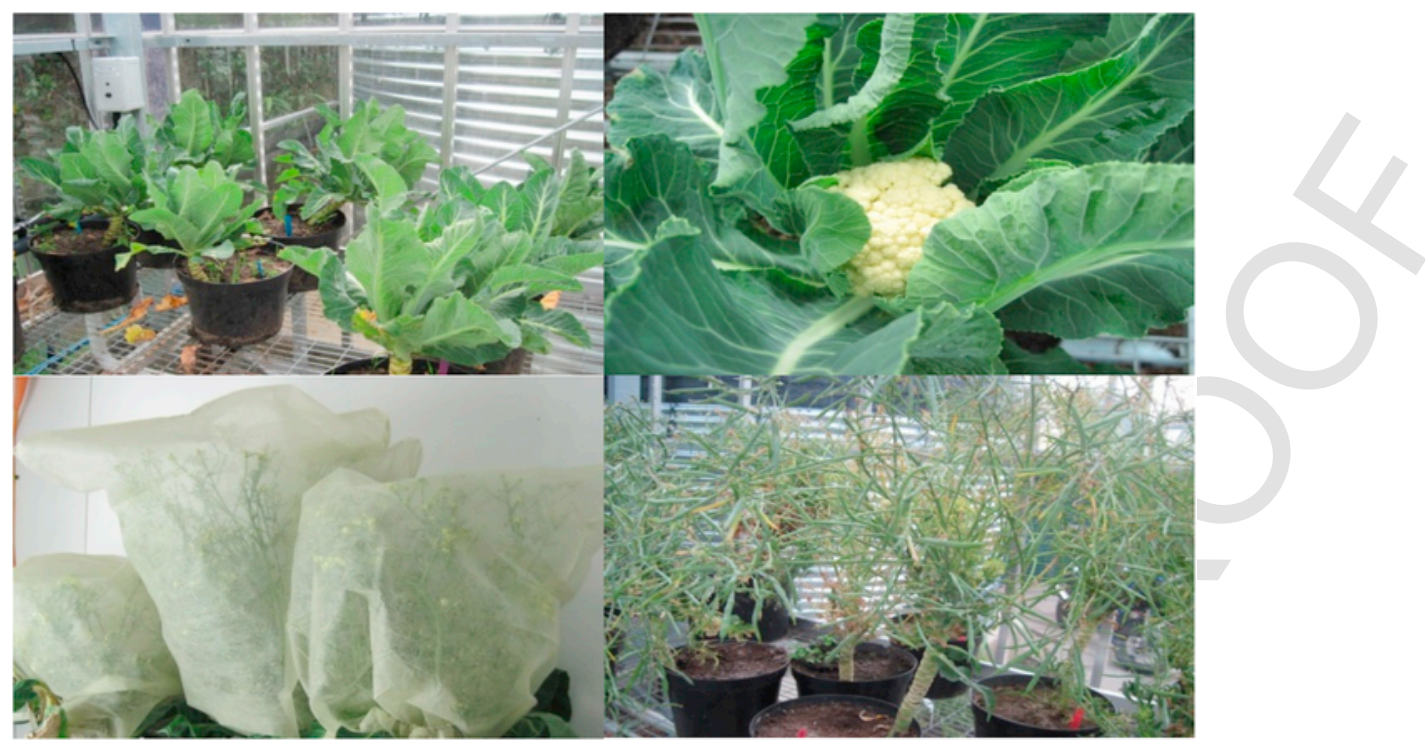

Fig. 1. The growth stages of cauliflower plants used for seed production.

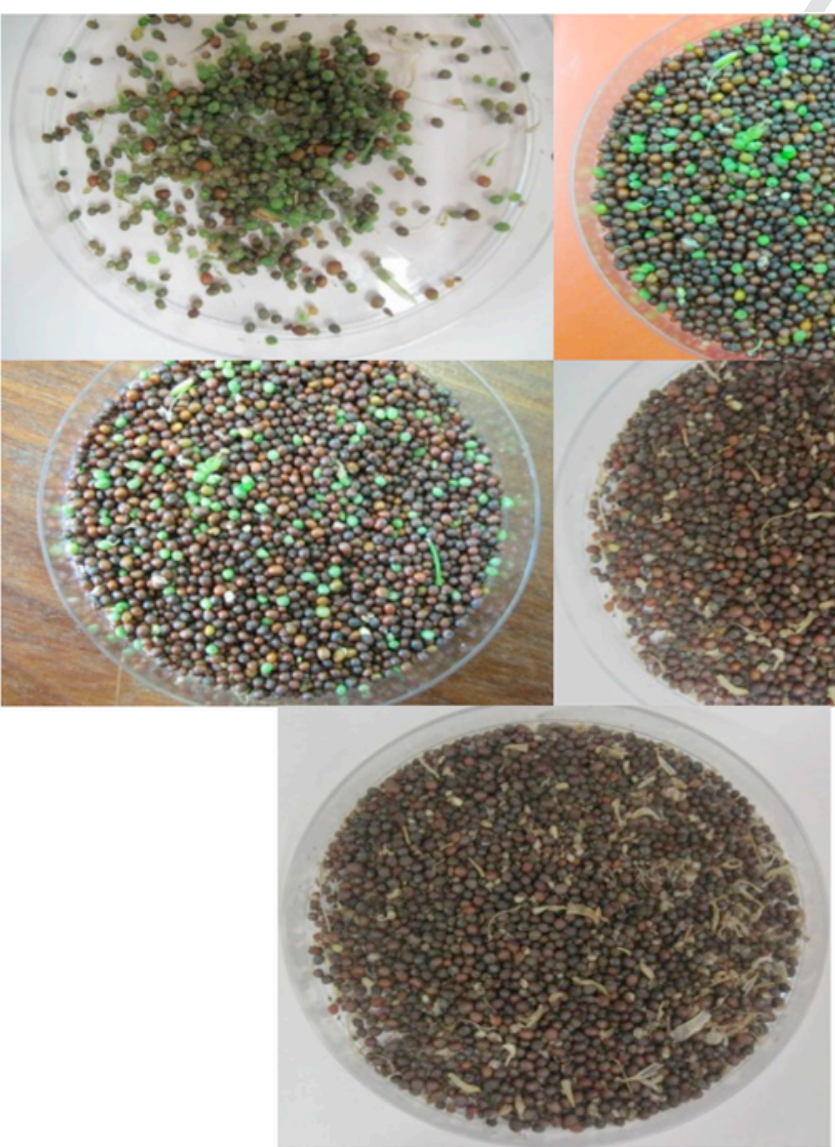

Fig. 2. Cauliflower seed samples at different developmental stages. 
Three replicates, each consisting of $0.6 \mathrm{~g}$ of ground seeds, were used for each seed sample.

\subsection{Determination of nitrogen content (Kjeldahl method)}

Kjeldahl method was used to determine the nitrogen content (Rihan, 2014). Three replicates each consisting of $0.12 \mathrm{~g}$ of ground seeds were used for each sample.

\subsection{Determination of ash content}

Samples were dried at $550{ }^{\circ} \mathrm{C}$ for $8 \mathrm{~h}$. The ash level was calculated using the following equation:

$$
\% \text { Ash }=\frac{\text { weight of residue }(\mathrm{g})}{\text { sample weight }(\mathrm{g})} * 100
$$

\subsection{Determination of carbohydrate level}

The carbohydrate content in the dried cauliflower seeds was determined by subtraction:

$$
\begin{aligned}
\% \text { Carbohydrate }=100- & (\% \text { moisture }+\% \text { Ash } \\
& +\% \text { Protein }+\% \text { Lipids })
\end{aligned}
$$

All the seed components analysis was carried out in the nutrition laboratory at Plymouth University.

\subsection{Protein extraction and immunoblotting for dehydrin protein detection}

The total proteins from each sample were extracted as described previously by $\mathrm{Ni}$ et al. (1996). Samples from $-80{ }^{\circ} \mathrm{C}$ were thawed on ice, placed in a mortar and pestle and $2 \mathrm{~mL}$ extraction buffer $(100 \mathrm{mM}$ potassium phosphate, $1 \mathrm{mM}$ DTT, $1 \mathrm{mM}$ EDTA, $1 \%$ Triton X-100, $10 \%$ glycerol, $\mathrm{pH} 7.8$ ) was added to $1 \mathrm{~g}$ of tissues and ground. One $\mathrm{mL}$ of the liquid grindate was transferred to a microfuge tube $(1.5 \mathrm{~mL})$ on ice. The supernatant was centrifuged twice at $13,000 \mathrm{xG}$ for 15 and $10 \mathrm{~min}$, respectively, at $4{ }^{\circ} \mathrm{C}$. The total protein content was evaluated using a bicinchoninic acid (BCA) assay kit (Pierce, product NO. 2161297A) following the manufacturer's instructions. The clear supernatant containing proteins was separated using SDS-PAGE (Sodium dodecyl sulfate polyacrylamide gel electrophoresis) (Laemmli, 1970) and visualized using Coomassie blue staining solution. Unstained gels were used for immunoblotting and the proteins were transferred to a PVDF membrane (pore size $0.4 \mu \mathrm{m}$ ) (Milipore, Cat. No ISE000010) by electro-blotting at $100 \mathrm{~V}$ for $35 \mathrm{~min} 1 \times$ Tris glycine transfer buffer was prepared by dissolving Tris $\mathrm{HCl} 3.05 \mathrm{~g} \mathrm{~L}^{-1}$, Glycine $14.4 \mathrm{~g} \mathrm{~L}^{-1}$, and adding methanol $200 \mathrm{ml} \mathrm{L}^{-1}$ of dH2O (Towbin et al., 1979). After transferring the proteins onto the PVDF membrane, the membrane was blocked using PBST (phosphate buffer saline +0.05 Tween $20 \%$ ) $+5 \%$ Marvel (a low fat skimmed milk powder) (Iceland Ltd) for $1 \mathrm{~h}$ at room temperature with mild shaking. After incubation, hybridization for the antibody raised against the K-segment of dehydrins was achieved with primary antibodies obtained from Dr Michael Wisniewski ‘s Laboratory, (USDA-ARS, Appalachian Fruit Research Station, USA). Membranes were incubated with dehydrin primary antibodies (produced in rabbit). Antibodies were diluted (1:1000) in a total volume of $20 \mathrm{~mL}$
PBST supplemented with $4 \%$ of semi skimmed milk and the membranes were incubated overnight at $4{ }^{\circ} \mathrm{C}$ with gentle agitation. The membranes were then washed 3 times with PBST while agitating to wash off the excess primary antibody, for $5 \mathrm{~min}$ each and the membrane was then incubated with horseradish peroxidase conjugated goat anti-rabbit IgG secondary antibody (PBS diluted 1:20,000) (Abcam) for an hour at room temperature with mild shaking to detect primary antibodies attached to the dehydrin protein. To ensure the specificity for dehydrin, antibodies were blocked using a peptide-salt containing the dehydrin K-segment consensus peptide TGEKKGIMDKIKEKLPGQH kindly provided by Prof Timothy J. Close (University of California, Riverside, USA). The peptide-salt $(0.5 \mathrm{~g})$ was dissolved in PBS and equal volumes of the peptide salt $\left(5 \mathrm{mg} \mathrm{mL}^{-1}\right)$ and dehydrin antibody serum (1:1000) were mixed and left for $30 \mathrm{~min}$. Antigen-blocked serum was then used instead of the primary antibody. The remaining protocol steps as above were then followed.

The membranes were washed 3 times with PBS for 5 min each and then incubated with ECL detection reagent (Luminata crescendo western HRP substrate (Millipore, WBLUR0100)) in the dark for $5 \mathrm{~min}$ and the image from the membrane was captured using a UVP gel documentation system. Blots were observed and digital images made.

The same procedures were applied with all samples to detect histone $\mathrm{H} 3$ protein (Agrisera, Art no: AS10 710) as a housekeeping reference protein. Histone antibody was diluted (1:5000) in a total volume of $20 \mathrm{~mL}$ PBST. Histone protein band intensities were used to normalize the intensities of dehydrin protein bands using Image J software (Java image processing program).

\subsection{The effect of acclimation on the accumulation of dehydrin proteins in cauliflower microshoots}

Cauliflower microshoots (cv. Dionis, Bred by Vilmorin (in France). Sold in the UK by Hazera UK) were obtained following procedures described in Rihan et al. (2011a) and the same protocol was used to produce cauliflower microshoots throughout this study. The 26 day old cultures were transferred to the cold room at $4{ }^{\circ} \mathrm{C}$ for acclimation. Cauliflower cultures were left in the cold room for 15 days for acclimation and the accumulation of dehydrin protein was investigated using the procedure described above.

\subsection{The effect of mannitol used with the culture media on the accumulation of dehydrin proteins in cauliflower microshoots}

Cauliflower microshoots (cv. Fremont, Bred by Seminis in Holland) were produced. Culture media were prepared to have several osmotic potentials by the addition of mannitol as follows,: mannitol free culture media osmotic potential of -0.47 Osmol kg-1 ( $-1.14 \mathrm{MPa}$ at lab temperature $21 \mathrm{C}$ ) (this media contained $3 \%$ of sucrose), -0.7 Osmol kg-1 (-1.712 MPa), -1.15 Osmol kg-1 (-2.812 MPa), -1.60 Osmol kg-1 (-3.913 MPa), -2.05 Osmol kg-1 (-5.014 MPa), -2.50 Osmol kg-1 (-4.946 MPa) and -2.95 Osmol kg-1 (-7.215 MPa). 28 day old microshoots were used to investigate the accumulation of dehydrin proteins under the effect of mannitol treatments.

\subsection{The effects of ABA on the accumulation of dehydrin proteins in acclimated cauliflower microshoots}

Cauliflower microshoots (cv. Cool, S\&G seeds (Syngenta)) were produced with five concentrations of ABA (Sigma-Aldrich, A-7631) $\left(0,0.5,1,2,4 \mathrm{mg} \mathrm{L}^{-1}\right)$ added to the culture medium. 21 day old cauli- 
flower microshoots cultures were transferred to the cold room at $4{ }^{\circ} \mathrm{C}$ for 15 days for acclimation. Dehydrin protein accumulation in the cauliflower microshoots was assessed.

\subsection{The effect of molybdenum on the accumulation of dehydrin proteins in acclimated cauliflower microshoots}

Cauliflower microshoots (cv. Cool) were produced with three concentrations of Mo $(0,15$ and $30 \mathrm{ppm})$ used with the culture media. The shaker containing the 25 day old microshoots was transferred from room temperature to the cold room at $4{ }^{\circ} \mathrm{C}$ for 15 days for acclimation. The accumulation of dehydrin proteins in the cauliflower microshoots was assessed.

\section{Statistical analysis}

Each experiment was repeated 3 times. Results are presented as means \pm standard error (SE). All data were subjected to analysis of variance (ANOVA) using Minitab software (version 15) and comparisons of means were made with least significant difference test (LSD) at $5 \%$ level of probability.

\section{Results}

\subsection{The development of cauliflower seed structure (moisture, lipids,} carbohydrate and ash)

Seed moisture level was quite high at the beginning of seed formation $(76 \%)$ and it started decreasing gradually with the development of the seeds. At the end of seed maturation, the moisture level was about $8 \%$. At that point, the seed pods had become very dry and were starting to dehisce and fall from the plants. The level of ash increased from about $1.2 \%$ to about $5 \%$ and the level of protein increased to $28.7 \%$ after 75 days of pollination ( $20 \%$ moisture level) (physiological maturation) followed by a decrease in the level of total protein to about $23 \%$ (Fig. 3).

The level of lipids increased from about $4.5 \%$ at the beginning of seed development to reach about $24 \%$ at the end of seed development. The level of carbohydrate was about $9 \%$ at the beginning of seed development and reached about $39 \%$ at the end of seed maturation (Fig. 4).

\subsection{The accumulation of dehydrin proteins during the development of cauliflower seeds}

No dehydrin bands were detected when blocked dehydrin antibody was used as a primary antibody (Fig. 6) illustrating the specificity of the antibody (see Fig. 5). Proteins at several molecular weights were detected by the K-segment dehydrin antibody at 12, 17, 26, 50 and $78 \mathrm{kDa}$. The results demonstrated that dehydrin proteins at 12,17 and 26 molecular weights displayed a very highly significant increase during the development of cauliflower seeds $(P<0.001$ for protein of 12 and $17 \mathrm{kDa}$ size classes and $P=0.002$ for protein of size class $26 \mathrm{kDa}$ ). The amount of these proteins was stabilized at a specific stage of seed development when the moisture level was assessed to be about 50\% (60 days from pollination) (Figs. 6 and 7). The amounts of high molecular weight dehydrin proteins at sizes 45 and $78 \mathrm{kDa}$ were significantly decreased during the development of cauliflower seeds $(P<0.001$ for protein of size class $78 \mathrm{kDa}$ and $P=0.015$ for protein of size class $48 \mathrm{kDa}$ ). However, the relative amounts of these proteins were very low compared to the proteins observed at the small molecular weight sizes (12, 17 and $26 \mathrm{kDa})$ (Figs. 6 and 7).

A dehydrin protein of size class $78 \mathrm{kDa}$ was observed in the immunoblotting experiment but not in the SDS PAGE analysis and this could have been due to the low amount of this protein in the seed sample and because immunoblotting is a more sensitive approach for detecting a specific type of protein.

\subsection{The effect of mannitol on the accumulation of dehydrin proteins in cauliflower microshoots}

The use of mannitol with the cauliflower microshoots liquid culture media significantly increased the amount of dehydrin protein of $35 \mathrm{kDa}$ size class $(P<0.001)$. However, the amount of this protein stabilized using the liquid culture media with osmotic pressure lower than $-1.14 \mathrm{MPa}$. In terms of the effect of mannitol on the accumulation of dehydrin protein of 78 and $170 \mathrm{kDa}$ size classes, it was observed that mannitol significantly increased the accumulation of these

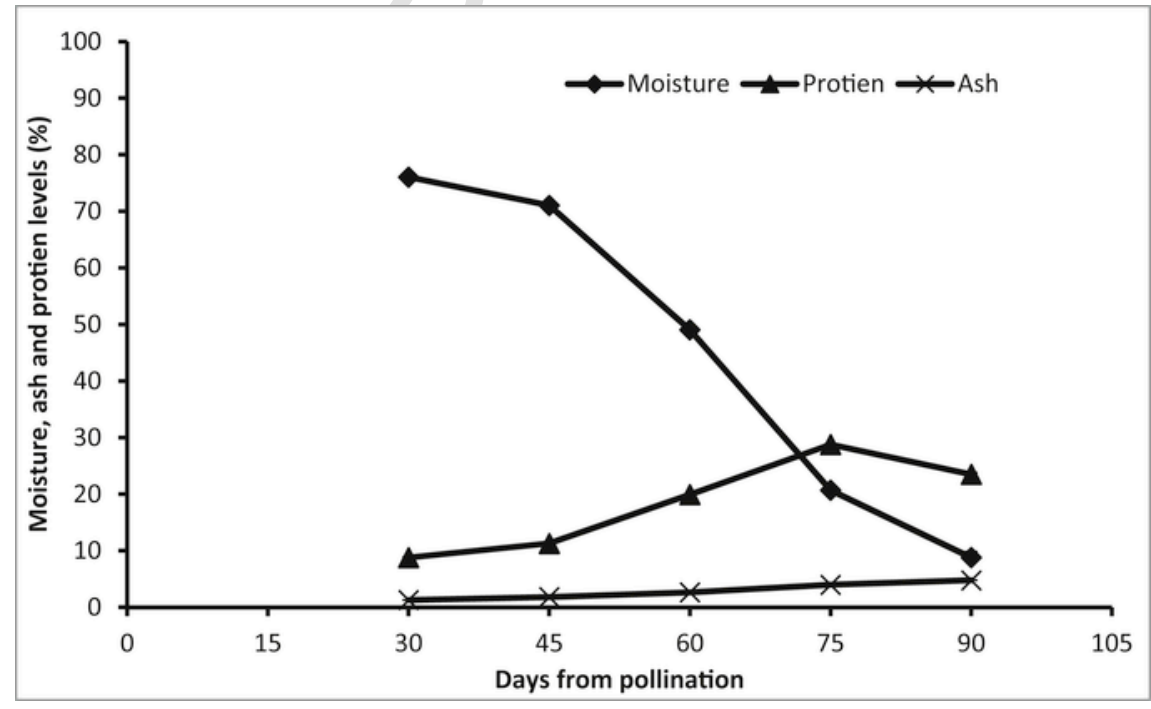

Fig. 3. Moisture, protein and ash level changes during the development of cauliflower seeds. 

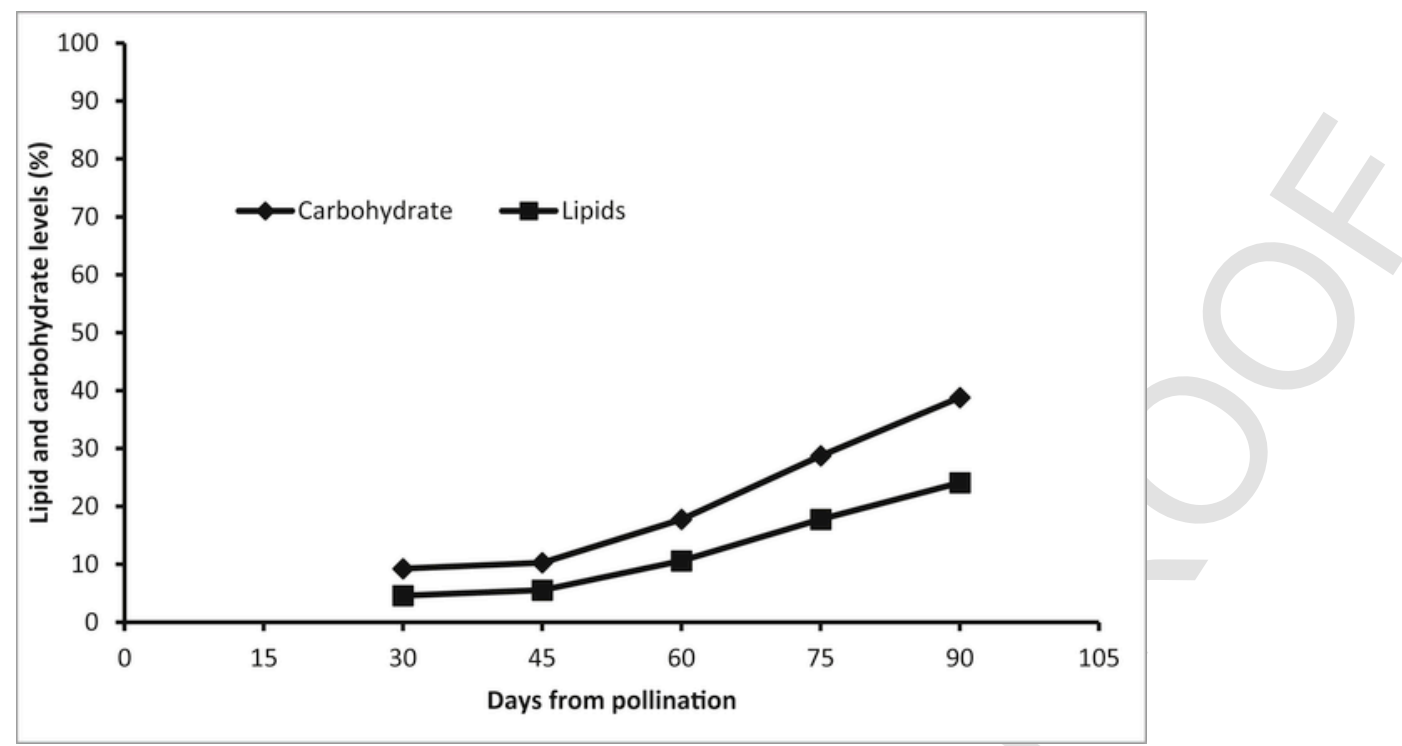

Fig. 4. Carbohydrate and lipid level changes during the development of cauliflower seeds.

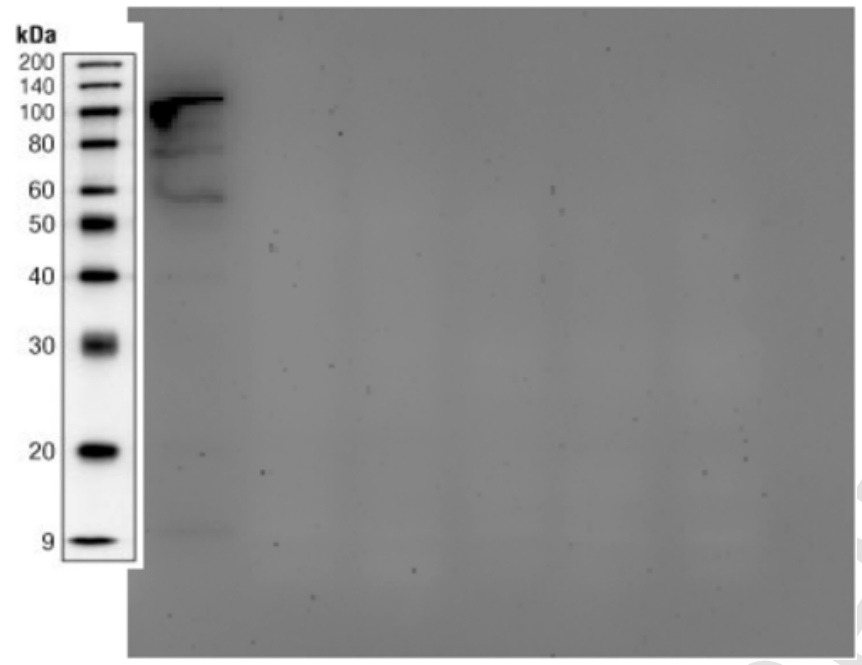

Fig. 5. Immunoblot analysis for the detection of dehydrin proteins from cauliflower artificial seeds at different developmental stages using a blocked dehydrin k-segment antibody.

proteins, reaching a peak at $-5.014 \mathrm{MPa}$ liquid culture media osmotic pressure $(P<0.001)$ followed by a significant decrease at lower culture osmotic pressures. However, the microshoots produced from culture media that have an osmotic pressure lower than $-5.014 \mathrm{MPa}$ were not capable of being encapsulated as artificial seeds (conversion rate $=0$ at this osmotic pressure i.e. lower than $-5.014 \mathrm{MPa})$ as reported by Rihan (2014) (Figs. 8 and 9) which suggests that these proteins are important in regard to the viability of cauliflower microshoots.

\subsection{The effect of cold acclimation on the accumulation of dehydrin protein in cauliflower microshoots}

Acclimation was observed to have no significant effect in cauliflower microshoots on the amount of dehydrin proteins at $79,22,35$ and $37 \mathrm{kDa}$ size classes $(P=0.110$ for protein of size class $79 \mathrm{kDa}$, $P=0.265$ for protein of size class $22, P=0.219$ for the protein of size class $35 \mathrm{kDa}$ and $P=0.125$ for protein of size class of $37 \mathrm{kDa}$ ). Acclimation, however, significantly decreased the amount of dehydrin protein of $28 \mathrm{kDa}$ size class $(P=0.004)$ (Figs. 10 and 11$)$.

\subsection{The effect of $A B A$ on the accumulation of dehydrin protein in acclimated cauliflower microshoots}

The use of ABA significantly increased the accumulation of dehydrin proteins at $78,53,50$ and $35 \mathrm{kDa}$ size classes $(P=0.008$, $P=0.001, P=0.010$ and $P<0.001$ at $35,78,50$ and $53 \mathrm{kDa}$ protein size classes, respectively) (Figs. 12 and 13). However, while the amount of dehydrin protein of size $35 \mathrm{kDa}$ stabilized after a specific concentration of ABA assessed to be $1 \mathrm{mg} \mathrm{L}^{-1}$, the amount of dehydrin proteins at 78,50 and $35 \mathrm{kDa}$ significantly decreased using concentrations of ABA higher than $2 \mathrm{mg} \mathrm{L}^{-1}$ with proteins at size classes 53 and $78 \mathrm{kDa}$ and with concentration higher than $1 \mathrm{mg} \mathrm{L}^{-1}$ with protein of size class $50 \mathrm{kDa}$ (Figs. 12 and 13). Moreover, the use of $2 \mathrm{mg} \mathrm{L}^{-1}$ increased the level of dehydrin protein of $62 \mathrm{kDa}$ which was not observed clearly using the other ABA treatments. Therefore, the use of $2 \mathrm{mg} \mathrm{L}^{-1}$ of ABA was recommended to stimulate the maximum accumulation of dehydrin proteins in the cauliflower microshoots (see Fig. 14).

\subsection{The effect of molybdenum on the accumulation of dehydrin proteins in acclimated cauliflower microshoots}

The use of molybdenum in acclimated cauliflower culture media significantly decreased the amount of dehydrin proteins at 78, 35 and $50 \mathrm{kDa}(P<0.001$ for protein of size class $78 \mathrm{kDa}, P=0.001$ for protein $35 \mathrm{kDa}$ and $P=0.040$ for protein of size class $50 \mathrm{kDa}$ ). However, the effect of Mo on the amount of dehydrin protein of size class $53 \mathrm{kDa}$ was found to be not significant $(P=0.087)$ (Figs. 14 and 15).

\section{Discussion}

Seed moisture content at the early stages of seed development was high (about 80\%) and decreased during maturation to a final level of $8 \%$ as expected. The high level of moisture is very necessary, especially at the early stages of seed development since water is the vehi- 
A

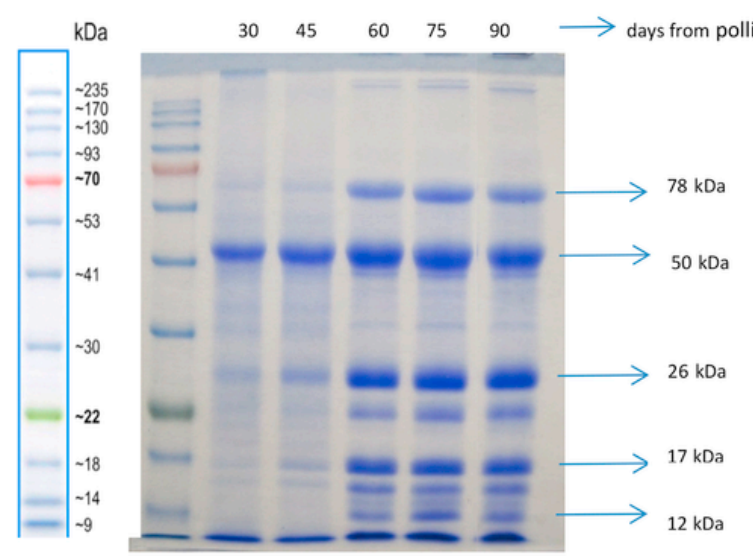

B

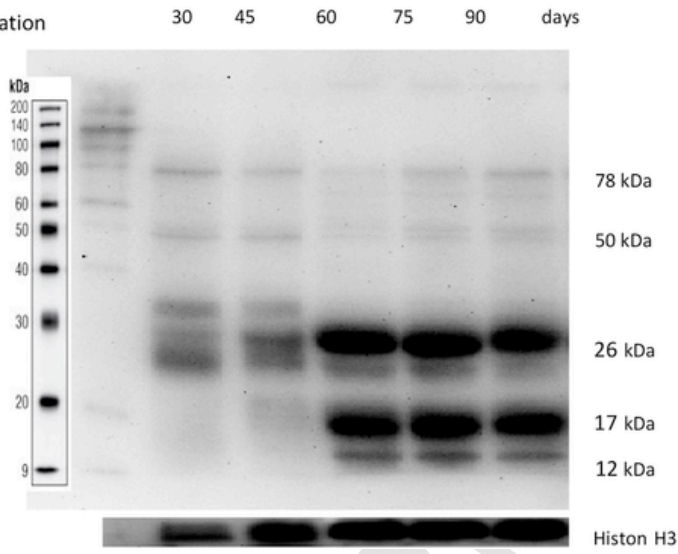

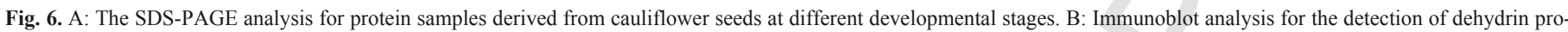
teins from cauliflower artificial seeds at different developmental stages using a k-segment dehydrin antibody.
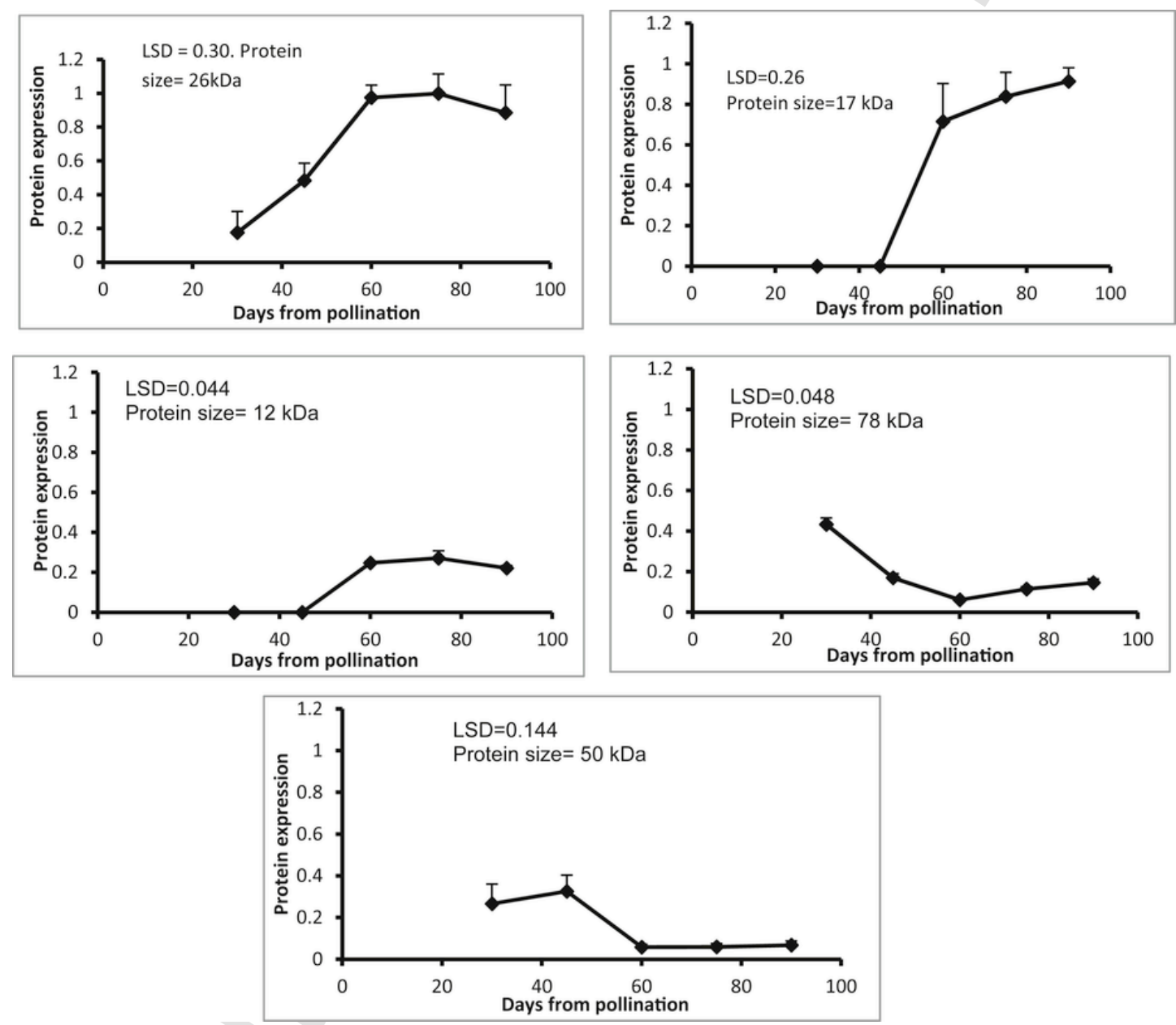

Fig. 7. The accumulation of dehydrin proteins during the development of cauliflower seeds.

cle for transferring nutrients from the parent plant to the developing embryo and cotyledons.

The process of seed development comprises consecutive stages that may be considered as preparation for successful future germina- tion and seed development is characterised by synthesis and accumulation of food reserves and the development of the embryo. One of the main metabolic activities that occurs during the development of seeds is the conversion of sucrose via glycolysis to oil and lipids 
A

Culture osmotic potential (MPa)

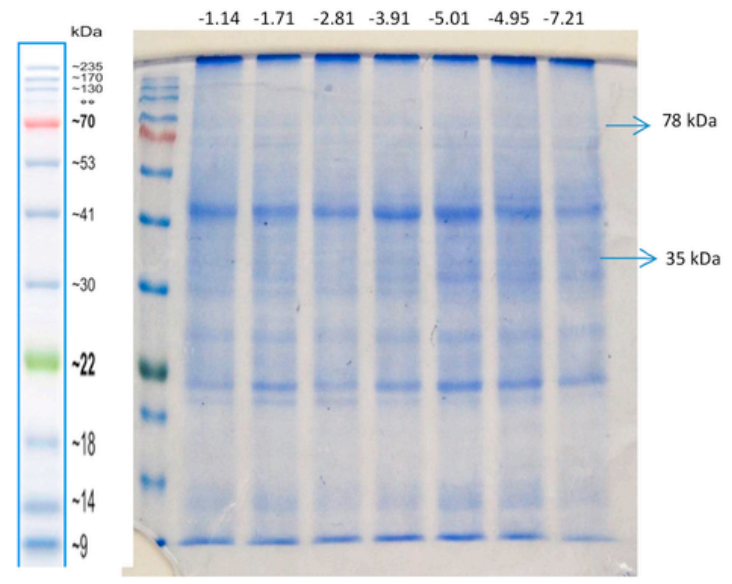

B

Culture osmotic potential (MPa)

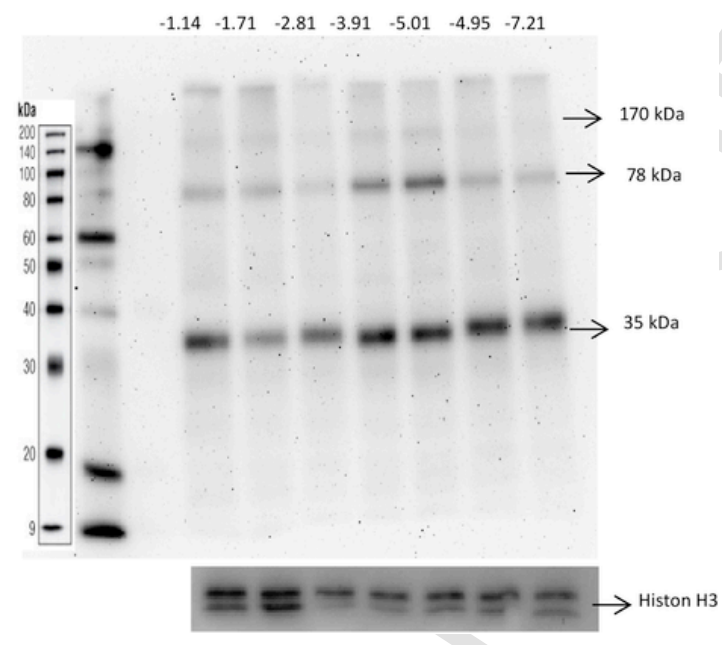

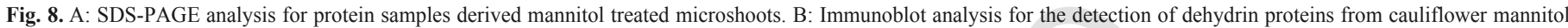
treated microshoots using a k-segment dehydrin antibody.

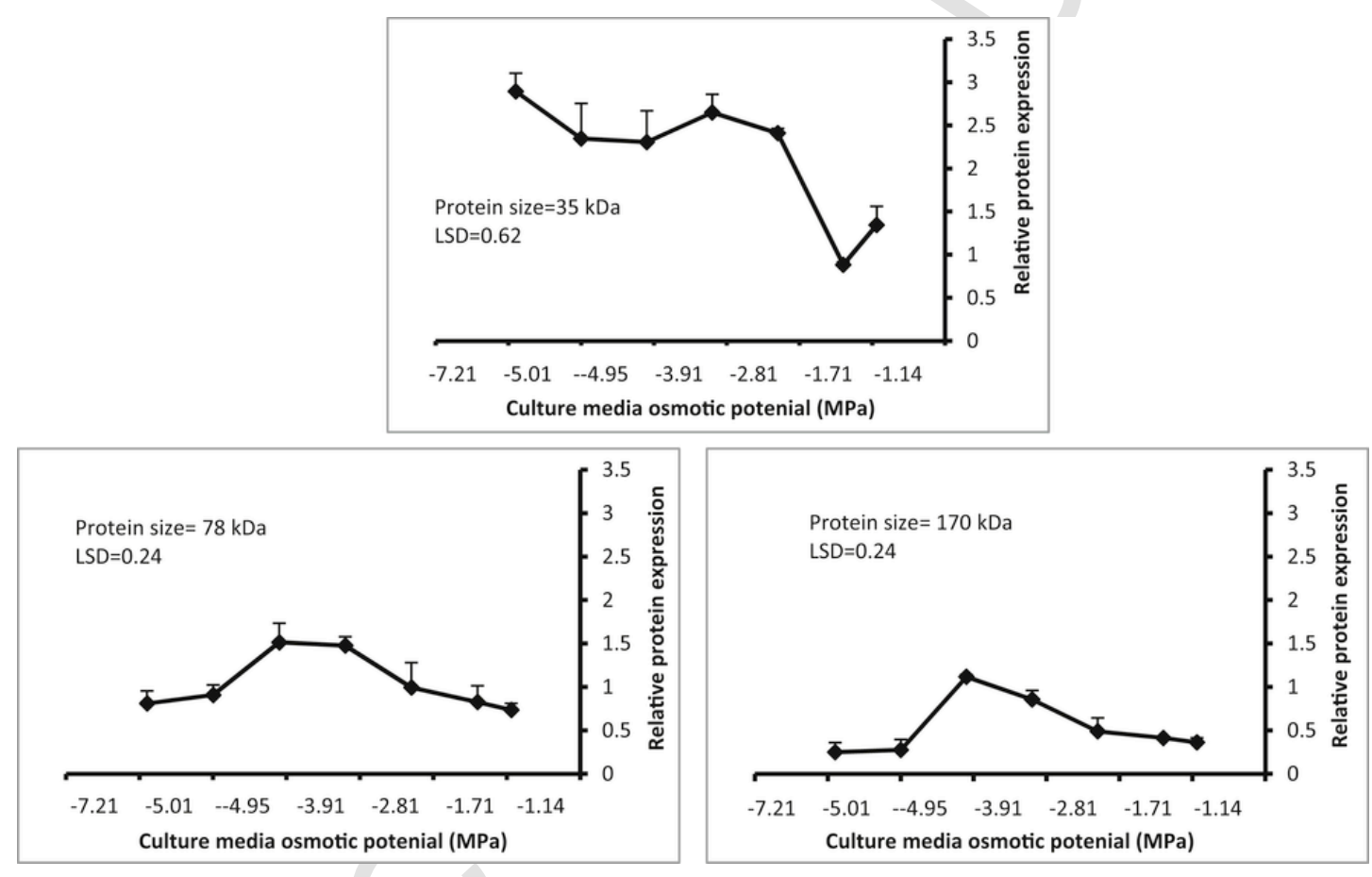

Fig. 9. The accumulation of dehydrin proteins in mannitol treated microshoots.

(Wei et al., 2008; Baud et al., 2008). However, the lipid synthesis during the development of seeds depends on the supply of several precursors such as, sucrose acetate (Vigeolas and Geigenberger, 2004), glucose 6-phosphate, pyruvate, phosphoenol pyruvate and malate (Rawsthorne, 2002). The developing embryo accumulates lipids in several forms such as, triacylglycerols (TAG), fatty acids and ester of glycerol when the early morphogenesis stage is completed. The fatty acid biosynthesis pathway during the development of seeds includes various subcellular compartments and is well understood (Baud et al., 2002). Lipids are stored in cytosolic oil bodies that form almost $60 \%$ of the cell volume in the cotyledons of mature embryos of Arabidopsis thaliana which is a crucifer as is cauliflower (Mansfield and Briarty, 1992). The accumulation of lipids is necessary to supply the required energy for seedling growth after germination (Siloto et al., 2006). During germination, the oil is degraded, providing energy and carbon to seedlings in their early growth stages through the consecutive operation of $\beta$-oxidation, glyoxylate cycle, partial tricarboxylic acid (TCA) cycle and gluconeogenesis (Chia et al., 2005). However, although several studies have reported that the level of lipids could decrease during the seed maturation of oil seeds such as Crambe abyssinica, Nicotiana tabacum, Arabidopsis and B. napus (Tomlinson et al., 2004; Baud et al., 2002; Norton and Harris, 

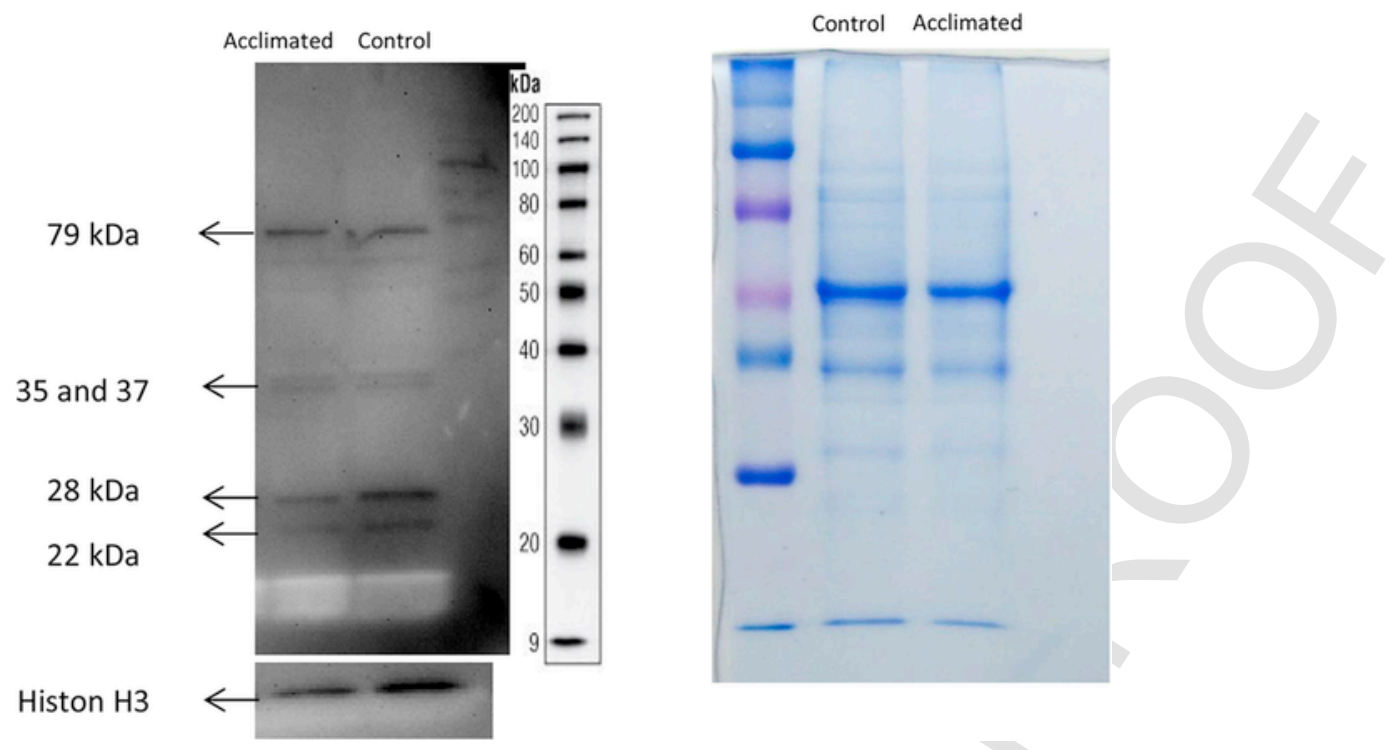

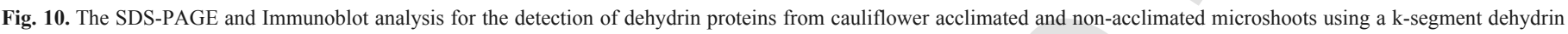
antibody.

1975; Gurr et al., 1972), this does not seem to be the case with cauliflower seeds since no decrease in the lipid level was observed during seed maturation. Moreover, the lipids accumulated to about $24 \%$ of the seed component when the seed moisture was assessed to be around $8 \%$ which accords with the findings of Gurusamy and Thiagarajan, (1998).

Soluble carbohydrates can act as cryprotectants, antioxidants and osmotic regulators in salt and drought stressed plants (Nkang, 2002). Sucrose has a fundamental function in the development of seeds as a main form of transportation of energy and carbon for most plant species and as a regulator of gene expression (Da Silva Bonome et al., 2011). Seeds are non-photosynthetic structures and are therefore very dependent on sucrose importation. However, as the first step for the production of storage products is hydrolysis of sucrose, the cleavage of sucrose to hexose is essential for plants (Koch, 2004). There are two enzyme pathways for sucrose hydrolysis in plants and these pathways are catalysed by sucrose synthase (SuSy) and invertases. It has been suggested that SuSy and invertases play an essential role for the transitions between seed development phases (Weschke et al., 2003; Baud et al., 2002). Acid invertase activity and hexose/sucrose ratio were observed to be high in the cell wall in the early stages of the seed development of many cereals such as rice (Hirose et al., 2002) and barley (Weschke et al., 2000). However, while the invertase activity increases following the transition of the embryonic expansion stage to the storage stage, the SuSy activity increases in the storage stage and this induces the synthesis of the cell wall, starch and other reserve components (Winter and Huber, 2000). Several researchers have shown that the gene expression for the invertases happen predominantly in the first stages of seed development while the expression of SuSy genes occurs in the intermediate and final stages of the development. These changes could control the transition from the division and expansion stage to the storage of reserve compounds (Borisjuk et al., 1998). This could explain the relatively sharp increase in carbohydrates level in the final developmental stages of cauliflower seeds and this is in agreement with Nkang (2002) who reported that carbohydrates such as starch and sucrose increase through the development of $E$. caffra seeds with a sharp increase during the final stages of the development.
Seed proteins are mainly produced in the cotyledons throughout the mid to late development stages of seed development. Amino acids are transferred from the phloem into the maternal seed tissue from where they are transferred to the seed and, consequently, taken up by the embryo (Golombek et al., 2001). The level of cauliflower seed total proteins increased to reach the maximum (assessed to be about $28 \%$ ) at seed moisture level around $20 \%$. After that, the level of protein decreased to about $23 \%$ at moisture level around $8 \%$. However, the small reduction in the level of protein in the late stages of cauliflower seed developments is in agreement with that reported by Gurusamy and Thiagarajan (1998) who found that the small decrease in the cauliflower seed protein content observed at the late stages of seed development could be caused by its utilization in growth.

Although several studies have reported the important role of carbohydrate in seed desiccation tolerance, recent studies have demonstrated that carbohydrates alone are insufficient to protect against desiccation (Bettey et al., 1998). It has been suggested that a set of heat-stable, late-embryogenesis-abundant (LEA) proteins has an essential role in the seed desiccation capacity (Blackman et al., 1991; Dure et al., 1989).

A very highly significant increase in the amount of relatively low molecular weight dehydrin proteins $(12,26$ and $6 \mathrm{kDa})$ was observed here during the development of cauliflower seeds, especially when the moisture level dropped below 50\%. However, although a slightly significant decrease in the amount of dehydrin proteins at relatively high molecular weights was found, this was considered to be unimportant since these proteins were of much lower abundance than the low molecular weight dehydrin proteins. The current results accord with the findings of Kalemba and Pukacka (2008) who reported that dehydrins are produced during the development of seeds as an element of the embryogenesis program and that they accumulate in response to seed desiccation. Dehydrins were observed in different plant species, such as several recalcitrant seeds of Castanospermum australe L., Clausena lansium (Lour.) and the orthodox woody plant seeds of Acer platanoides L. (Finch-Savage and Blake, 1994). Dehydrins are thought to bind and stabilise cell lipids and membrane structure under abiotic stresses (Rorat, 2006). Farrant et al. (2004) and Close (1997) demonstrated that acquisition of desiccation tolerance of orthodox seeds is linked with an accumulation of late embryogene- 


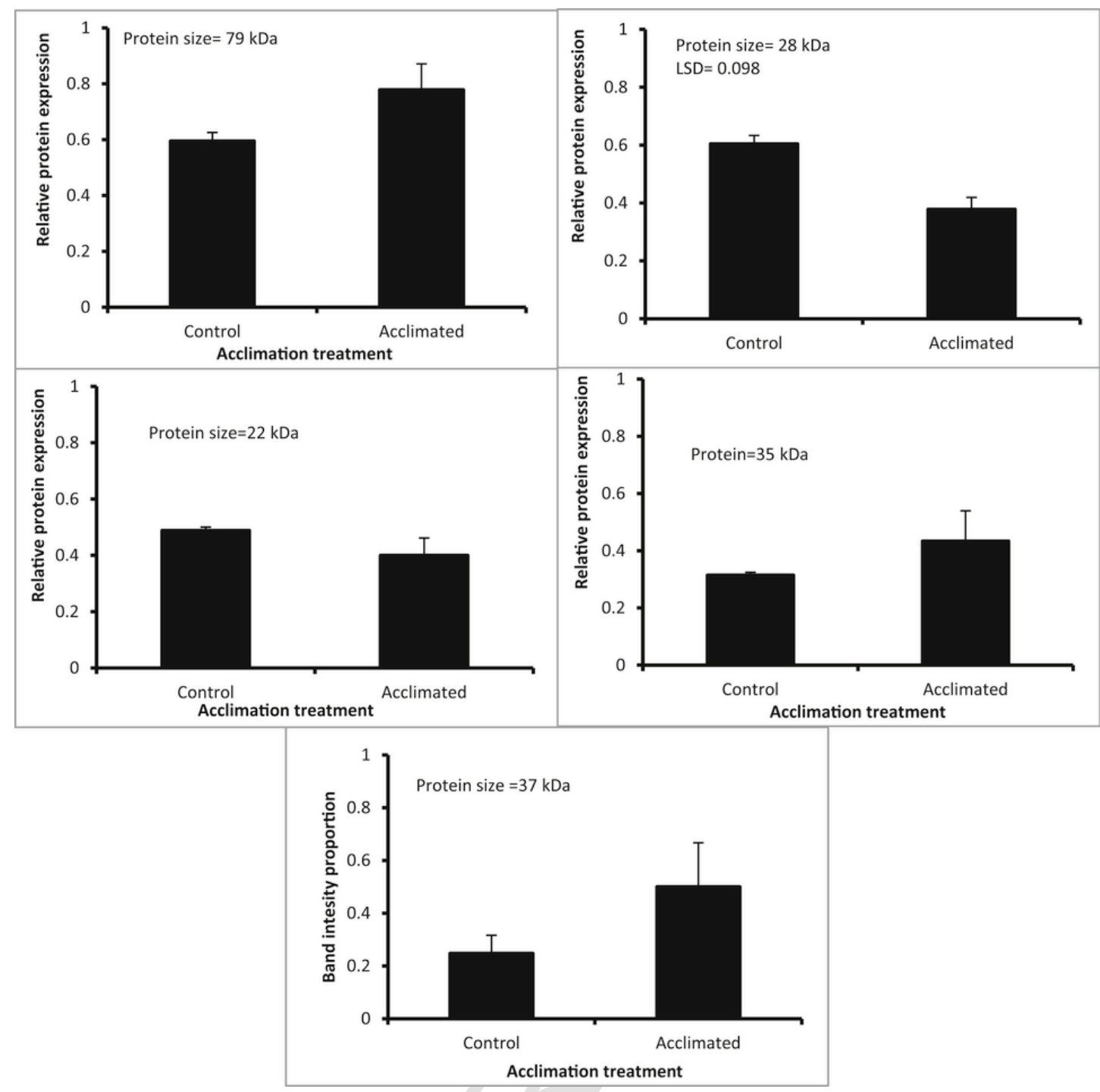

Fig. 11. The effect of cold acclimation on the accumulation of dehydrin proteins in cauliflower microshoots.

sis abundant (LEA) proteins. Goyal et al. (2005) indicated that LEA proteins could play an essential part in protecting the cellular or molecular structure from the damaging effect of water loss. It was also demonstrated that dehydrin proteins protect cells under drought stress by protecting the structure of proteins and preserving their water binding (Garnczarska et al., 2008; Farrant et al., 2004). The amino acid composition of dehydrin proteins with a high content of charged and polar residues could support their specific protective roles under environments of cell dehydration (Rorat, 2006; Allagulova et al., 2003).

Considering the important role of dehydrin proteins in seed abiotic stress tolerance, several experiments were conducted here aimed at increasing the amount of these proteins in cauliflower microshoots which in turn might improve cauliflower artificial seed abiotic stress tolerance. Moreover, the cauliflower micropropagation system applied in the current studies facilitates the investigation of molecular response of specific stressor or protective elements such as mannitol, Mo and ABA, applied with the liquid culture media taking advantage of the huge number of microshoots that can be produced from the culture system. However, culture systems have been widely used for molecular and physiological studies since they have potential advan- tages over whole plants (Tal, 1983) including the homogeneity of the plant culture population, the capacity of easily repeating the experiments under controlled conditions and the possibility of isolating the culture response from the whole plant response (Parmentier-Line et al., 2002)

The effect of various materials on the accumulation of dehydrin proteins in cauliflower microshoots was investigated. However, the protein bands detected were observed to be of different molecular sizes depending on the cauliflower variety used and this could be due to the various genetic backgrounds of these varieties. In agreement with the hypothesis put forward here, different studies have reported dehydrin proteins at different size classes, for example, while Battaglia et al. (2008) reported that most of the described Brassica dehydrins range from 19 to $22 \mathrm{kDa}$ with the only exception of $31 \mathrm{kDa}$ ERD10 dehydrin of Brassica napus. Rurek (2010) was able to detect dehydrin proteins at several other size classes such as 40, 50, 55 and $70 \mathrm{kDa}$.

The effect of drought stimulation using a high osmotic pressure solution of mannitol with culture liquid media was determined. 78 and $170 \mathrm{kDa}$ proteins seem to play an essential role in relation to the viability of cauliflower microshoots since the artificial seeds using 
A

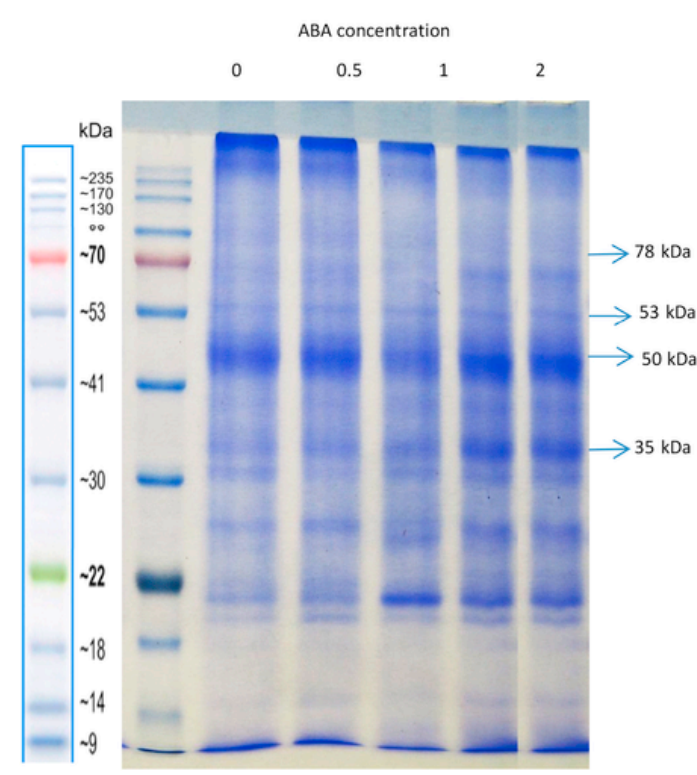

B

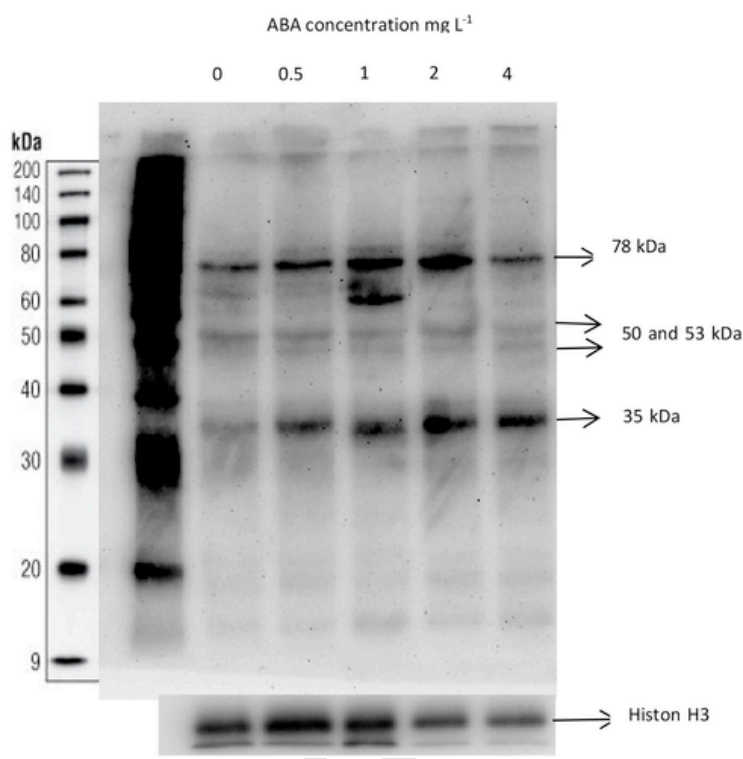

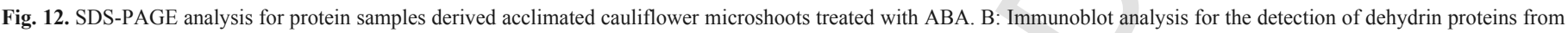
cauliflower acclimated microshoots treated with ABA using a k-segment dehydrin antibody.
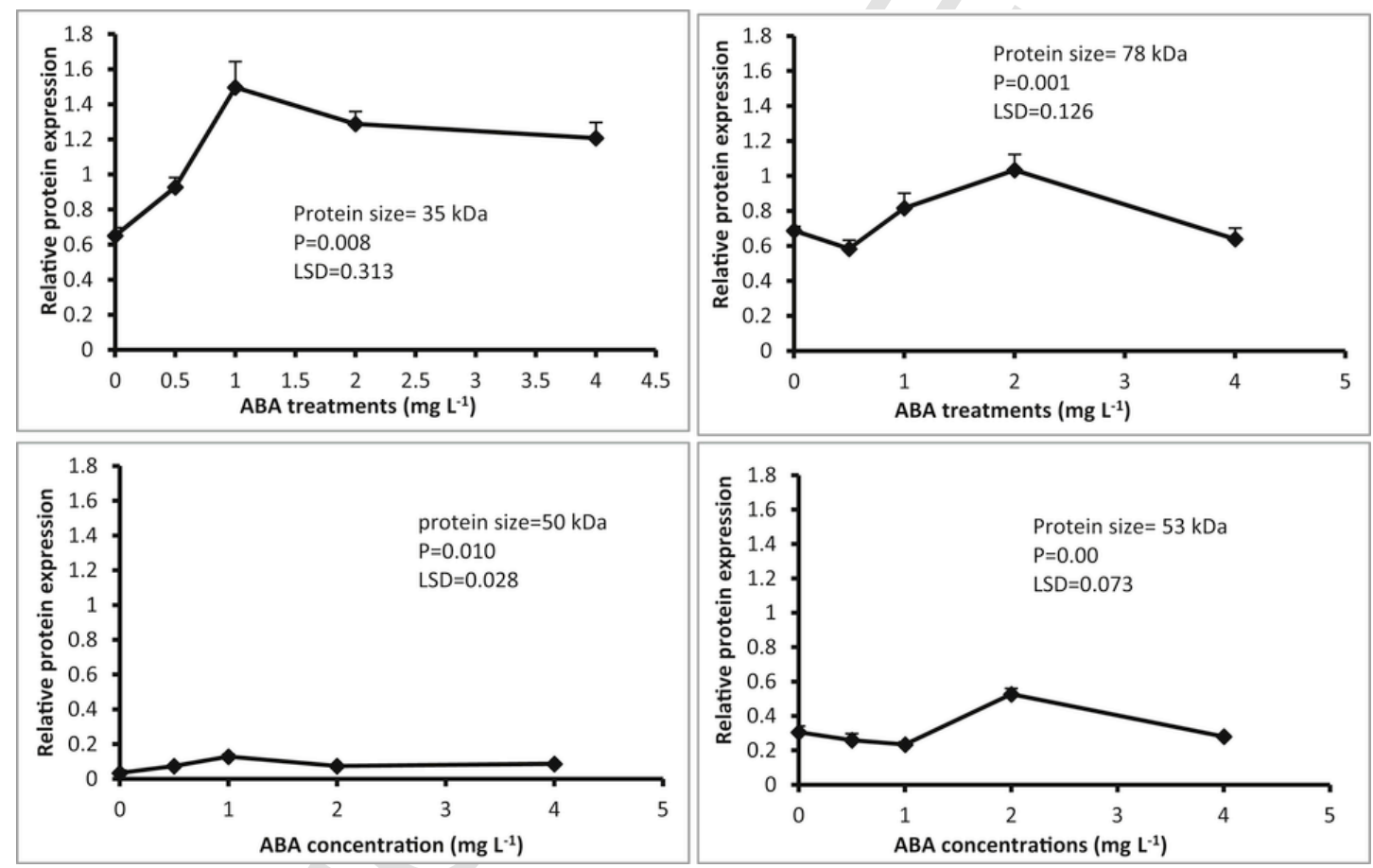

Fig. 13. The effect of ABA used with cauliflower microshoots liquid culture media on the accumulation of dehydrin proteins in the acclimated cauliflower microshoots.

microshoots derived from lower than $-5.014 \mathrm{MPa}$ osmotic pressure showed no germination capacity (Rihan et al., 2014). However, dehydrin proteins have been reported to increase in response to dehydration stress (Cellier et al., 1998; Han and Kermode, 1996; Welin et al., 1994) and non-penetrating osmotic agents such as mannitol, which reduce the osmotic potential of the culture media and are widely used to induce the osmotic potential of the cultured cell in woody and herbaceous plants (Leustek and Kirby, 1990; Fallon and Phillips, 1989; Leustek and Kirby, 1988; Bhaskaran et al., 1985).
Several studies have reported the increase of dehydrin proteins resulting from low temperature treatments and acclimation (Welin et al., 1994). Muthalif and Rowland (1994) and Panta et al. (2001) reported the accumulation of dehydrin proteins in whole blueberry plants under the effect of low but non-freezing temperature while Parmentier-Line et al. (2002) reported the accumulation of these proteins in cold treated blueberry cell cultures. However, although several studies have reported the accumulation of dehydrin proteins during the acclimation of Arabidopsis, Fragaria, Brassica, Miscanthus 

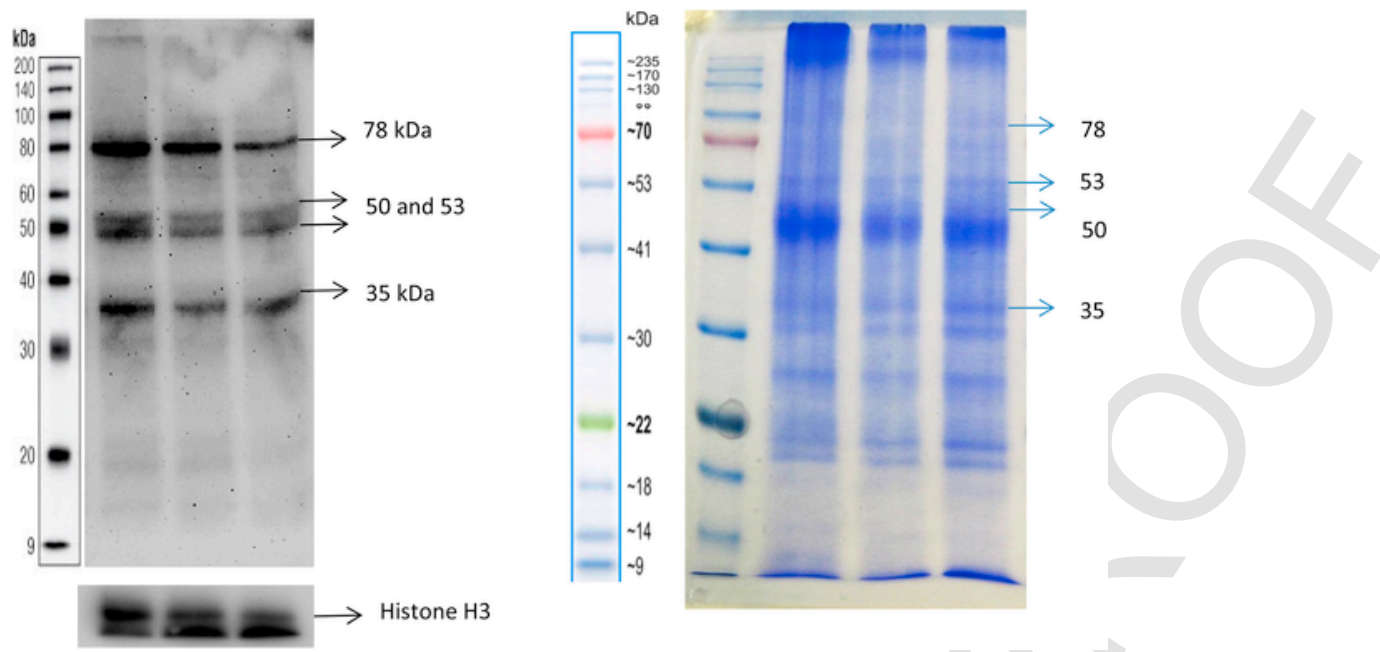

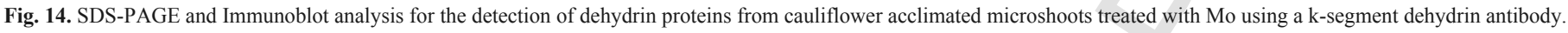



Fig. 15. The effect of Mo used with cauliflower microshoots liquid culture media on the accumulation of dehydrin proteins in the acclimated cauliflower microshoots.

and woody plant species of genus Prunus, Cydonia (Baniulis et al., 2012, Rugienius et al., 2009; Lukoševičiūtè et al., 2009, Nishizawa et al., 2008; Patton et al., 2007; Wisniewski et al., 2006; Welling et al., 2004), the amount of these in cauliflower microshoots was not significantly affected by cold acclimation. Moreover, the acclimation significantly decreased the amount of $28 \mathrm{kDa}$ dehydrin protein. This could be due to the culture conditions as a liquid media and reproductive tissue have been used for cauliflower microshoot production and these conditions may have affected the cauliflower microshoots' response to cold acclimation. Kovalchuk et al. (2009) reported that the composition of culture media plays an essential role in the acclimation of plant microshoots and cold tolerance under in vitro conditions. It could also be that the cold treatment might have been too long and the cold-induced peak in dehydrin accumulation could probably have been detected earlier. However, this needs further investigation.

As cold acclimation was reported here to have no role in the accumulation of dehydrin proteins in cauliflower miroshoots and as the process of acclimation was reported to improve the cold tolerance of cauliflower microshoots, an important question was raised about the role of dehydrin proteins in cauliflower microshoots cold tolerance. Therefore, the effect of some materials, which were reported to have negative (ABA) or positive (Mo) effects on acclimated cauliflower microshoots cold tolerance (ABA), their effect on the accumulation of dehydrin proteins in cauliflower microshoots was investigated. The use of ABA at 1 and $2 \mathrm{mg} \mathrm{L}^{-1}$ significantly increased the level of dehydrin proteins at various dehydrin size classes. However, Zhang et al. (2006) indicated that ABA is one of the most central stress sig- 
nal transduction pathways of plant responses to abiotic stress. In agreement with the current results, several studies have demonstrated the positive responses of several dehydrin proteins to exogenous $\mathrm{ABA}$ application or diverse stresses that involved ABA as regulator (Close, 1996; Nylander et al., 2001). Schroeder et al. (1987) and Kao et al. (1996) have also demonstrated that the accumulation of dehydrin proteins could be induced by the application of exogenous ABA in cultured embryos. Moreover, working with ABA deficient mutants in $A$. thaliana (Leonkloosterziel et al., 1996; Paiva and Kriz, 1994; Nelson et al., 1994) and maize (Mori and Muto, 1997; Pla et al., 1993), the significant effect of endogenous ABA on the induction of LEA protein gene expression was demonstrated. Although exogenous ABA significantly increased the accumulation dehydrin proteins, it did not improve their cold tolerance indicating that there is no significant role of dehydrin proteins in the cold tolerance of cauliflower microshoots. However, more research is still required to determine the effect of dehydrin proteins on the cold tolerance of cauliflower.

The application of molybdenum to the cauliflower culture media decreased the accumulation of dehydrin proteins at different size classes. This indicates again that dehydrin proteins have no significant effect on the cold tolerance of cauliflower microshoots since molybdenum was confirmed earlier in this thesis to significantly improve the cold tolerance of the microshoots (Rihan et al., 2014). Molybdenum has an essential role on the synthesis of ABA (Huang et al., 2009) and ABA was confirmed to have positive effects on the accumulation of dehydrin in cauliflower microshoots. Molybdenum has a negative effect on the accumulation of these proteins. It should be mentioned that molybdenum has an essential role in several enzymes in plants such as nitrate reductase, aldehyde oxidase, xanthine dehydrogenase and sulphite oxidase (Mendel and Hansch, 2002). However, to the best of our knowledge, this is the first study to determine the effect of molybdenum on the accumulation of dehydrin proteins in plants and further investigations are required to determine the mechanism which molybdenum decreases the accumulation of dehydrins.

\section{Conclusion}

The chemical changes that occur during the development of cauliflower seeds were determined and the accumulation of dehydrin proteins during the development of the seeds was confirmed. Several chemical materials were applied to the cauliflower microshoots culture media with the aim of increasing the level of dehydrin proteins in order to simulate the structure of cauliflower traditional seeds in artificial seeds. The addition of these chemical materials also enabled an investigation into the possible contribution made by dehydrins to microshoot cold tolerance. Several treatment reported in this study, such as mannitol and ABA treatments, significantly increased the level of dehydrin accumulation in cauliflower microshoots. This is turns played an important role to improve the quality of artificial seed produced. Interestingly, the current results suggest that dehydrin proteins make no significant contribution to cauliflower microshoot cold tolerance. The research helps to improve the understanding of molecular aspects and the role of dehydrin proteins in plant abiotic stress tolerance.

\section{Contribution}

Dr Rihan and Dr Al-Issawi conducted the experiments in Professor Mick Fuller's laboratory at Plymouth University/UK.

Dr Hail Rihan wrote the paper.
Dr Al-Issawi helped in the laboratory work and statistical analysis.

Professor Mick Fuller supervised the laboratory work, helped in the statistical analysis and edited the article.

\section{Acknowledgment}

The authors gratefully acknowledge the provision of a $\mathrm{PhD}$ grant from the University of Damascus, Syria. The author also acknowledge the fellowship grant from CARA (the Council for At-Risk Academics).

\section{References}

Allagulova, C.R., Gimalov, F., Shakirova, F., Vakhitov, V., 2003. The plant dehydrins: structure and putative functions. Biochem. Mosc. 68, 945-951.

Anisko, T., Lindstrom, O.M., 1996. Seasonal changes in cold hardiness of Rhododendron L.Catawbiense Boursault'Grown under continuous and periodic water stress. J. Am. Soc. Hortic. Sci. 121, 301-306.

Baniulis, D., Stepulaitiene, I., Lukoseviciute, V., Blazyte, A., Stanys, V., Rugienius, R., Sasnauskas, A., 2012. Accumulation of Dehydrin-Like Proteins in Pear (pyrus communis 1.) Microshoots During Cold Acclimation.

Battaglia, M., Olvera-Carrillo, Y., Garciarrubio, A., Campos, F., covarrubias, A.A., 2008. The enigmatic LEA proteins and other hydrophilins. Plant physiol. 148, 6-24.

Baud, S., Boutin, J.P., Miquel, M., Lepiniec, L., Rochat, C., 2002. An integrated overview of seed development in Arabidopsis thaliana ecotype WS. Plant Physiol. Biochem. 40, 151-160

Baud, S., Dubreucq, B., Miquel, M., Rochat, C., Lepiniec, L., 2008. Storage reserve accumulation in Arabidopsis: metabolic and developmental control of seed filling. Arabidopsis Book/Am. Soc. Plant Biol. 6.

Bettey, M., Sinniah, U.M.A.R., Finch-Savage, W., Ellis, R., 1998. Irrigation and seed quality development in rapid-cycling Brassica: accumulation of stress proteins. Ann. Bot. 82, 657-663.

Bewley, J.D., Black, M., 1994. Seeds: Physiology of Development and Germination. Springer.

Bhaskaran, S., Smith, R.H., Newton, R.J., 1985. Physiological changes in cultured sorghum cells in response to induced water stress I. Free proline. Plant physiol. 79, 266-269.

Blackman, S.A., Wettlaufer, S.H., Obendorf, R.L., Leopold, A.C., 1991. Maturation proteins associated with desiccation tolerance in soybean. Plant physiol. $96,868-874$.

Borisjuk, L., Walenta, S., Weber, H., Mueller-Klieser, W., Wobus, U., 1998. High-resolution histographical mapping of glucose concentrations in developing cotyledons ofVicia fabain relation to mitotic activity and storage processes: glucose as a possible developmental trigger. Plant J. 15, 583-591.

Bray, E.A., 1993. Molecular responses to water deficit. Plant physiol. 103, 1035.

Ceccardi, T.L., Meyer, N.C., Close, T.J., 1994. Purification of a maize dehydrin. Protein Expr. Purif. 5, 266-269.

Cellier, F., Conéjéro, G., Breitler, J.C., Casse, F., 1998. Molecular and physiological responses to water deficit in drought-tolerant and drought-sensitive lines of sunflower accumulation of dehydrin transcripts correlates with tolerance. Plant physiol. 116, 319-328.

Chia, T.Y.P., Pike, M.J., Rawsthorne, S., 2005. Storage oil breakdown during embryo development of Brassica napus (L.). J. Exp. Bot. 56, 1285-1296.

Close, T.J., 1997. Dehydrins: a commonalty in the response of plants to dehydration and low temperature. Physiol. Plant. 100, 291-296.

Close, T.J., 1996. Dehydrins: emergence of a biochemical role of a family of plant dehydration proteins. Physiol. Plant. 97, 795-803.

Close, T.J., Kortt, A.A., Chandler, P.M., 1989. A cDNA-based comparison of dehydration-induced proteins (dehydrins) in barley and corn. Plant Mol. Biol. 13, 95-108.

Coelho, C.M.M., Benedito, V.A., 2008. Seed development and reserve compound accumulation in common bean (Phaseolus vulgaris L.). Seed Sci. Biotechnol. 2, 42-52.

Da Silva Bonome, L.T., Moreira, S.A.F., De Oliveira, L.E.M., De Jesus Sotero, A., 2011. Metabolism of carbohydrates during the development of seeds of the brazilian rubber tree [Hevea brasiliensis (Willd. Ex Adr. de Juss) Muell.-Arg.]. Acta Physiol. Plant. 33, 211-219.

Delouche, J., 1971. Seed Maturation. Handbook of Seed Technology. Mississipi State University, Mississipi, 17-21.

Dure, I., 2001. Occurrence of a repeating 11-mer amino acid sequence motif in diverse organisms. Protein Peptide Lett. 8, 115-122.

Dure, L., Crouch, M., Harada, J., Ho, T.H.D., Mundy, J., Quatrano, R., Thomas, T., Sung, Z., 1989. Common amino acid sequence domains among the LEA proteins of higher plants. Plant Mol. Biol. 12, 475-486. 
Fallon, K., Phillips, R., 1989. Responses to water stress in adapted and unadapted carrot cell suspension cultures. J. Exp. Bot. 40, 681-687.

Farrant, J.M., Bailly, C., Leymarie, J., Hamman, B., Côme, D., Corbineau, F., 2004 Wheat seedlings as a model to understand desiccation tolerance and sensitivity. Physiol. Plant. 120, 563-574.

Fei, H., Tsang, E., Cutler, A.J., 2007. Gene expression during seed maturation in $<\mathrm{i}>$ Brassica napus $</ i>$ in relation to the induction of secondary dormancy. Genomics 89, 419-428.

Fellows, R., Pfeiffer, T., Egli, D., Tekrony, D., Balles, J., 1979. Physiological maturity in soybean. Agron. J. 71, 771-775.

Finch-Savage, W.E., Blake, P.S., 1994. Indeterminate development in desiccation-sensitive seeds of Quercus robur L. Seed Sci. Res. 4, 127-133.

Garay-Arroyo, A., Colmenero-Flores, J.M., Garciarrubio, A., Covarrubias, A.A., 2000 Highly hydrophilic proteins in prokaryotes and eukaryotes are common during conditions of water deficit. J. Biol. Chem. 275, 5668-5674.

Garnczarska, M., Zalewski, T., Wojtyla, , 2008. A comparative study of water distribution and dehydrin protein localization in maturing pea seeds. J. plant Physiol. 165, 1940-1946.

Golombek, S., Rolletschek, H., Wobus, U., Weber, H., 2001. Control of storage protein accumulation during legume seed development. J. plant Physiol. 158, 457-464.

Goyal, K., Walton, L.J., Tunnacliffe, A., 2005. LEA proteins prevent protein aggregation due to water stress. Biochem. J. 388, 151.

Gurr, M.I., Blades, J., Appleby, R.S., 1972. Studies on seed-oil triglycerides - composition of crambe-abyssinica triglycerides during seed maturation. Eur. J. Biochem. 29. 362-\&.

Gurusamy, C., Thiagarajan, C., 1998. The pattern of seed development and maturation in clauliflower (Brassica oleracea L. var. botrytis). Phyt.-Horn 38, 259-268.

Han, B., Kermode, A.R., 1996. Dehydrin-like proteins in castor bean seeds and seedlings are differentially produced in response to ABA and water-deficit-related stresses. J. Exp. Bot. 47, 933-939.

Hirose, T., Takano, M., Terao, T., 2002. Cell wall invertase in developing rice caryopsis: molecular cloning of OsCIN1 and analysis of its expression in relation to its role in grain filling. Plant Cell Physiol. 43, 452-459.

Hoekstra, F.A., Golovina, E.A., Buitink, J., 2001. Mechanisms of plant desiccation tolerance. Trends plant Sci. 6, 431-438.

Huang, P.M., Chen, J.Y., Wang, S.J., 2009. Tissue-specific regulation of rice molybdenum cofactor sulfurase gene in response to salt stress and ABA. Acta Physiol. Plant. 31, 545-551.

Kalemba, E.M., Pukacka, S., 2008. Changes in late embryogenesis abundant proteins and a small heat shock protein during storage of beech $(<\mathrm{i}>$ Fagus sylvatica $</ \mathrm{i}>$ L.) seeds. Environ. Exp. Bot. 63, 274-280.

Kao, C.Y., Cocciolone, S.M., Vasil, I.K., Mccarty, D.R., 1996. Localization and interaction of the cis-acting elements for abscisic acid, VIVIPAROUS1, and light activation of the $\mathrm{C} 1$ gene of maize. Plant Cell 8, 1171-1179.

Kieffer, M., Simkins, N., Fuller, M.P., Jellings, A.J., 2001. A cost effective protocol for in vitro mass propagation of cauliflower. Plant Sci. 160, 1015-1024.

Koch, K., 2004. Sucrose metabolism: regulatory mechanisms and pivotal roles in sugar sensing and plant development. Curr. Opin. plant Biol. 7, 235-246.

Kovalchuk, I., lyudvikova, Y., Volgina, M., Reed, B.M., 2009. Medium, container and genotype all influence in vitro cold storage of apple germplasm. Plant Cell, tissue organ Cult. 96, 127-136.

Laemmli, U.K., 1970. Cleavage of structural proteins during the assembly of the head of bacteriophage T4. nature 227, 680-685.

Leonkloosterziel, K.M., Gil, M.A., Ruijs, G.J., Jacobsen, S.E., Olszewski, N.E., Schwartz, S.H., Zeevaart, J.A.D., Koornneef, M., 1996. Isolation and characterization of abscisic acid-deficient Arabidopsis mutants at two new loci. Plant J. 10, 655-661.

Leustek, T., Kirby, E., 1990. Selection and physiology of cell cultures of Douglas-fir grown under conditions of water stress. Tree Physiol. 6, 317-327.

Leustek, T., Kirby, E.G., 1988. The influence of glutamine on growth and viability of cell suspension cultures of Douglas-fir after exposure to polyethylene glycol. Tree Physiol. 4, 371-380.

Levitt, J., 1960. Some problems in drought resistance. Bulletin of the Research Council of Israel. Section D. Botany 8, 173-180.

Lisse, T., Bartels, D., Kalbitzer, H.R., Jaenicke, R., 1996. The recombinant dehydrin-like desiccation stress protein from the resurrection plant Craterostigma plantagineum displays no defined three-dimensional structure in its native state. Biol. Chem. 377, 555-562.

Lukoševičiūtė, V., Rugienius, R., Stanienè, G., Stanys, V., Baniulis, D., 2009. Thermostable protein expression during hardening of sweet and sour cherry microshoots in vitro. Sodinink. Ir. Daržinink. 28, 35-43.

Mansfield, S., Briarty, L., 1992. Cotyledon cell development in Arabidopsis thaliana during reserve deposition. Can. J. Bot. 70, 151-164.

Mendel, R.R., Hansch, R., 2002. Molybdoenzymes and molybdenum cofactor in plants. J. Exp. Bot. 53, 1689-1698.

Mori, I.C., Muto, S., 1997. Abscisic acid activates a 48-kilodalton protein kinase in guard cell protoplasts. Plant Physiol. 113, 833-839.
Muthalif, M.M., Rowland, L.J., 1994. Identification of dehydrin-like proteins responsive to chilling in floral buds of blueberry (Vaccinium, section Cyanococcus). Plant physiol. 104, 1439-1447.

Nelson, D., Salamini, F., Bartels, D., 1994. Abscisic-acid promotes novel dna-binding activity to a desiccation-related promoter of craterostigma-plantagineum. Plant J. 5, 451-458.

Ni, M., Dehesh, K., Tepperman, J.M., Quail, P.H., 1996. GT-2: in vivo transcriptional activation activity and definition of novel twin DNA binding domains with reciprocal target sequence selectivity. Plant Cell Online 8, 1041-1059.

Nishizawa, A., Yabuta, Y., Shigeoka, S., 2008. Galactinol and raffinose constitute a novel function to protect plants from oxidative damage. Plant physiol. $147,1251-1263$.

Nkang, A., 2002. Carbohydrate composition during seed development and germination in two sub-tropical rainforest tree species (Erythrina caffra and Guilfoylia monostylis). J. plant Physiol. 159, 473-483.

Norton, G., Harris, J.F., 1975. Compositional changes in developing rape seed (Brassica napus L.). Planta 123, 163-174.

Nylander, M., Svensson, J., Palva, E.T., Welin, B.V., 2001. Stress-induced accumulation and tissue-specific localization of dehydrins in Arabidopsis thaliana. Plant Mol. Biol. 45, 263-279.

Paiva, R., Kriz, A.L., 1994. Effect of abscisic-acid on embryo-specific gene-expression during normal and precocious germination in normal and viviparous maize (zea-mays) embryos. Planta 192, 332-339

Panta, G.R., Rieger, M.W., Rowland, L.J., 2001. Effect of cold and drought stress on blueberry dehydrin accumulation. J. Hortic. Sci. Biotechnol. 76, 549-556.

Parmentier-Line, C.M., Panta, G.R., Rowland, L.J., 2002. Changes in dehydrin expression associated with cold, ABA and PEG treatments in blueberry cell cultures. Plant Sci. 162, 273-282.

Patton, A.J., Cunningham, S.M., Volenec, J.J., Reicher, Z.J., 2007. Differences in freeze tolerance of zoysiagrasses: II. Carbohydrate and proline accumulation. Crop Sci. 47, 2170-2181.

Pla, M., Vilardell, J., Guiltinan, M.J., Marcotte, W.R., Niogret, M.F., Quatrano, R.S., Pages, M., 1993. The cis-regulatory element ccacgtgg is involved in aba and water-stress responses of the maize gene rab28. Plant Mol. Biol. 21, 259-266.

Rawsthorne, S., 2002. Carbon flux and fatty acid synthesis in plants. Prog. Lipid Res. 41, 182-196.

Rihan, H., 2014. Plant Tissue Culture and Artificial Seed Production Techniques for Cauliflower and Their Use to Study Molecular Analysis of Abiotic Stress Tolerance. PhD Plymouth University.

Rihan, H., Al-Issawi, M., Burchett, S., Fuller, M., 2011a. Encapsulation of cauliflower (var) microshoots as artificial seeds and their conversion and growth in commercial substrates. Plant Cell, Tissue Organ Cult. 2, 243-250.

Rihan, H.Z., Al Shamari, M., Fuller, M.P., 2012. The production of cauliflower microshoots using curd meristematic tissues and hypocotyl-derived callus. Acta Hort. (ISHS) 961, 427-434.

Rihan, H.Z., Al-Issawi, M., Al Shamari, M., Woldie, W.A., Kiernan, M., Fuller, M.P., 2014. The effect of molybdenum on the molecular control of cold tolerance in cauliflower (Brassica oleracea var. botrytis) artificial seeds. Plant Cell, Tissue Organ Cult. (PCTOC) 118, 215-228.

Rihan, H.Z., Al-Issawi, M., Burchett, S., Fuller, M.P., 2011b. Encapsulation of cauliflower (Brassica oleracea var botrytis) microshoots as artificial seeds and their conversion and growth in commercial substrates. Plant Cell, Tissue Organ Cult (PCTOC) 107, 243-250.

Roberts, J.K., Desimone, N.A., Lingle, W.L., Dure, L., 1993. Cellular concentrations and uniformity of cell-type accumulation of two lea proteins in cotton embryos. Plant Cell Online 5, 769-780.

Rorat, T., 2006. Plant dehydrins - tissue location, structure and function. Cell. Mol Biol. Lett. 11, 536-556.

Rugienius, R., Siksnianas, T., Gelvonauskiene, D., Staniene, G., Sasnauskas, A., Zalunskaite, I., Stanys, V., Zhivondov, A., Gercheva, P., Koumanov, K., 2009. Evaluation of genetic resources of fruit crops as donors of cold and disease resistance in Lithuania. Acta Hortic. 825, 117-124.

Rurek, M., 2010. Diverse accumulation of several dehydrin-like proteins in cauliflower (Brassica oleracea var. botrytis), Arabidopsis thaliana and yellow lupin (Lupinus luteus) mitochondria under cold and heat stress. BMC plant Biol. 10, 181.

Schroeder, J.I., Raschke, K., Neher, E., 1987. Voltage dependence of k+ channels in guard-cell protoplasts. Proc. Natl. Acad. Sci. U. S. A. 84, 4108-4112.

Shinozaki, K., Yamaguchi-Shinozaki, K., 2000. Molecular responses to dehydration and low temperature: differences and cross-talk between two stress signaling pathways. Curr. Opin. plant Biol. 3, 217-223.

Siloto, R.M.P., Findlay, K., Lopez-Villalobos, A., Yeung, E.C., Nykiforuk, C.L., Moloney, M.M., 2006. The accumulation of oleosins determines the size of seed oilbodies in Arabidopsis. Plant Cell Online 18, 1961-1974.

Steponkus, P.L., Rains, D., Valentine, R., Hollaender, A., 1980. A unified concept of stress in plants? Genetic engineering of osmoregulation. Impact plant Prod. food, Chem. energy 235-255.

Tal, M., 1983. Selection for stress tolerance. Handb. Plant Cell Cult. 1

Thomashow, M.F., 1999. Plant cold acclimation: freezing tolerance genes and regulatory mechanisms. Annu. Rev. Plant Physiol. Plant Mol. Biol. 50, 571-599. 
Tomlinson, K.L., Mchugh, S., Labbe, H., Grainger, J.L., James, L.E., Pomeroy, K.M., Mullin, J.W., Miller, S.S., Dennis, D.T., Miki, B.L.A., 2004. Evidence that the hexose-to-sucrose ratio does not control the switch to storage product accumulation in oilseeds: analysis of tobacco seed development and effects of overexpressing apoplastic invertase. J. Exp. Bot. 55, 2291-2303.

Towbin, H., Staehelin, T., Gordon, J., 1979. Electrophoretic transfer of proteins from polyacrylamide gels to nitrocellulose sheets: procedure and some applications. Proc. Natl. Acad. Sci. 76, 4350.

Vigeolas, H., Geigenberger, P., 2004. Increased levels of glycerol-3-phosphate lead to a stimulation of flux into triacylglycerol synthesis after supplying glycerol to developing seeds of Brassica napus L. in planta. Planta 219, 827-835.

Wei, W.H., Chen, B., Yan, X.H., Wang, L.J., Zhang, H.F., Cheng, J.P., Zhou, X.A., Sha, A.H., Shen, H., 2008. Identification of differentially expressed genes in soybean seeds differing in oil content. Plant Sci. 175, 663-673.

Welin, B.V., Olson, , Nylander, M., Palva, E.T., 1994. Characterization and differential expression of $\mathrm{dhn} / \mathrm{lea} / \mathrm{rab}$-like genes during cold acclimation and drought stress in Arabidopsis thaliana. Plant Mol. Biol. 26, 131-144.

Welling, A., Rinne, P., Viherä-Aarnio, A., Kontunen-Soppela, S., Heino, P., Palva, E.T., 2004. Photoperiod and temperature differentially regulate the expression of two dehydrin genes during overwintering of birch (Betula pubescens Ehrh.). J. Exp. Bot. 55, 507-516.

Weschke, W., Panitz, R., Gubatz, S., Wang, Q., Radchuk, R., Weber, H., Wobus, U., 2003. The role of invertases and hexose transporters in controlling sugar ratios in maternal and filial tissues of barley caryopses during early development. Plant J. 33, 395-411.

Weschke, W., Panitz, R., Sauer, N., Wang, Q., Neubohn, B., Weber, H., Wobus, U., 2000. Sucrose transport into barley seeds: molecular characterization of two transporters and implications for seed development and starch accumulation. Plant J. 21, 455-467.

Winter, H., Huber, S.C., 2000. Regulation of sucrose metabolism in higher plants: localization and regulation of activity of key enzymes. Crit. Rev. Biochem. Mol. Biol. 35, 253-289.

Wise, M., 2003. LEAping to conclusions: a computational reanalysis of late embryogenesis abundant proteins and their possible roles. Bmc Bioinforma. 4, 52.

Wisniewski, M.E., Bassett, C.L., Renaut, J., Farrell, R., Tworkoski, T., Artlip, T.S., 2006. Differential regulation of two dehydrin genes from peach (Prunus persica) by photoperiod, low temperature and water deficit. Tree Physiol. 26, 575-584.

Wolkers, W.F., Mccready, S., Brandt, W.F., Lindsey, G.G., Hoekstra, F.A., 2001. Isolation and characterization of a D-7 LEA protein from pollen that stabilizes glasses in vitro. Biochim. Biophys. Acta (BBA)-Protein Struct. Mol. Enzym. 1544, 196-206.

Zhang, J., Jia, W., Yang, J., Ismail, A.M., 2006. Role of ABA in integrating plant responses to drought and salt stresses. Field Crops Res. 97, 111-119. 